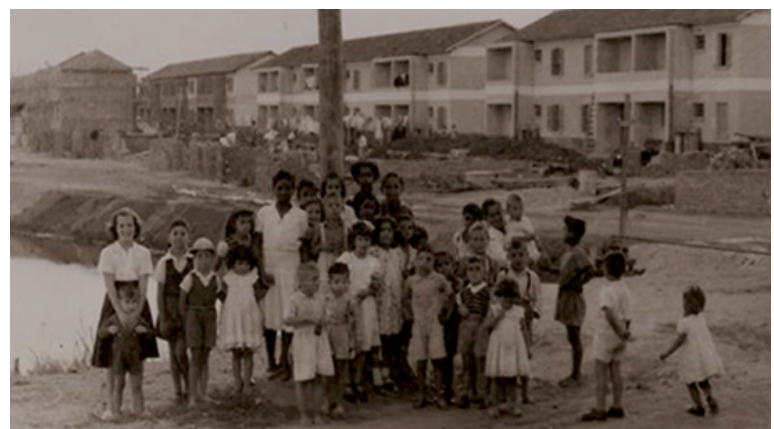

1. EntreVilas é um projeto coletivo, proposto pelo Centro de Pesquisa e Formação do SESC (São Paulo, Brasil), idealizado e coordenado por Marina Thomé e Márcia Mansur, do Estúdio CRUA. Participaram do projeto: Adriano Almeida, Ana Lucia Solidad Ribeiro de MagaIhães, Caio Dutra Profirio de Souza, Daniela Gonçalves, Débora Pinto, Glaucia Garcia, lolanda Depizzol, João Rocha Rodrigues, Lara $\mathrm{Na-}$ cht, Glória Branco, Maria Isabel Costa Menezes da Rocha, Naiara Magalhães, Rita de Cássia Campos Pereira e Taís Schiavon.

*Arquiteta e Urbanista pela UNESP (Bauru 2007-2011) Mestra em história gestão e valorização do Patrimônio Industrial, Master TPTI (Techniques, Patrimoine et Territoire de I Industrie, um convenio entre as universidades Paris 1 Panthéon Sorbonne Paris, França; Università Degli Studi di Padova, Padova Itália; Universidade de Évora, Évora, Portugal _ 2013 2015). Doutoranda em Arquitetura e Urbanismo, Universidade de Évora, Portugal (2015). Pesquisadora CIDEHUS-CHAIA (Universidade de Évora, Portugal)

usjt • arq.urb • número 24 | janeiro - abril de 2019

\title{
EntreVilas. Um traçado imaginário pelas vilas operárias de São Paulo. ${ }^{1}$
}

EntreVilas. An imaginary tracing through the company-towns of São Paullo

Taís Schiavon*

\section{Resumo}

EntreVilas pode ser visto como o primeiro documentário interativo a mergulhar no contexto das vilas operárias e trajetória de urbanização paulistana. Em um período em que as relações sociais e cotidianas são cada vez mais construídas no mundo virtual, proporcionar ao usuário diferentes experiências de imersão em contextos históricos (ricamente caracterizados por seus vestígios patrimoniais materiais e imateriais), poderia ser uma saída para a promoção de sua valorização e reconhecimento. Essa é uma das intenções do documentário interativo EntreVilas: permitir ao usuário percorrer as camadas históricas e contemporâneas de algumas das vilas operárias (company-towns) da cidade de São Paulo, revelando relatos devidamente narrados por seus moradores, reconstruindo neste contexto a conformação econômica, social e espacial da cidade de São Paulo, uma vez que a distribuição de vilas operárias e suas respectivas indústrias foram de fundamental importância para a atual consolidação urbana. O projeto registra o contexto em que essas vilas foram construídas bem como sua relevância ao longo do processo de expansão urbana, englobando o arco-temporal entre os anos de 1867-1959, narrando desde as normatizações sanitárias aos principais acontecimentos, sociais, políticos, econômicos envolvidos neste processo de desenvolvimento.

Palavras-chave: Patrimônio. Paisagens Culturais. Webdocumentário.

\section{Abstract}

EntreVilas could be seen as the first interactive documentary to delve into the context of company-towns and urbanization in São Paulo, discussing in this context, the historical and current relationships between work and housing. In a period where social and daily relationships are built in the virtual world, providing the user different experiences of immersion in historical contexts could be an outlet for the promotion of their valuation. This is one of the intentions of the interactive documentary Entre Vilas: allow the user to browse through the historical and contemporary layers of the Company-towns of São Paulo city, revealing their historical reports and the current conformation, telling by its residents, constructing in this way, the economic, social and spatial conformation of São Paulo. In this sense, the project discusses the relationships between work, housing and memory, recording the context in which these villages were built, as well as their relevance along the urban expansion process. The article analyzes the trajectory of part of the company-towns located in the capital, between the years 1867-1959, narrating in this way from the sanitary norms to the main events, social, political, economic and many other characteristics involved in this process of development.

Keywords: Heritage. Cultural Landscapes. Webdocumentary. 


\section{O uso da interatividade como forma de cons-} cientização e valorização patrimonial:

Ao considerarmos que a internet está revolucionando a forma como as pessoas se comunicam e utilizam os espaços urbanos, devemos ter em conta que essa revolução deve também ser estendida às demais correlações humanas, sobretudo às ações em torno de sua memória, cujas lembranças tornam-se efêmeras em meio às rápidas transições técnicas e tecnológicas. $\mathrm{A}$ própria internet pode ser vista como algo novo, uma vez que sua efetiva proliferação ocorre na década de 1990, um tempo curto, cujas transformações não permitem imaginar a continuidade das relações humanas sem seu funcionamento.

As novas medias na ótica da valorização do patrimônio e as possíveis formas de musealização.

Ao levarmos em conta as transições em meio à disseminação de conhecimentos, Machado (s/d, p.1540) relata que "o uso de novas medias e as consequências de sua massificação na socieda- de atual, é cada vez mais, ponto de análise e reflexão." Como forma de afirmar esse raciocínio, a mesma pesquisadora, cita o estudo de Castells (2002), que aponta o indiscutível potencial social das Tecnologias da Informação e da Comunicação (TIC's) na forma de pensar e agir de cada indivíduo. Em meio a estas transições as instituições museológicas demonstram significativas alterações ao longo dos anos, acompanhando tanto as discussões e os novos meios de popularização da informação, quanto sua gestão e valorização patrimonial, rompendo a limitação do espaço ao ambiente físico do museu, se tornando acessível a uma maior parcela de espectadores. Neste sentido é válida a citação de Moutinho (1989, p.102) que afirma que "a transformação da sociedade que levou à mudança dos parâmetros da Museologia".

Neste artigo, a análise da ação de museus e da possível criação de ambientes virtuais é de importância uma vez que, na grande maioria dos 
2. Como garantir a conservação desse patrimônio imaterial? Plataformas instáveis, sempre mudando tecnologias e mudando as prioridades de investimento - estas são as novas normas no setor de mídia de hoje. À medida que os olhos se voltam para a próxima grande inovação, os jogos digitais e a arte digital, os contos de histórias interativos e os webdocumentários produzidos há apenas cinco anos estão se tornando obsoletos.

\section{Tradução própria.}

4. O documentário pode ser acessado pela plataforma: http://entrevilasdoc.com.br/ casos, tais instituições tornam-se responsáveis pela gestão, valorização e reconhecimento público de determinado bem material, ou imaterial. Entretanto, sabemos que por muitas vezes esta ação é vista como um desafio, onde a disseminação cultural é dificultada por inúmeras variáveis que intimidam ou dificultam o acesso e o reconhecimento do usuário.

As novas mídias tornam-se instrumentos de importância à construção da comunicação aonde, "sua utilização como complemento do espaço físico do museu vem facilitar a transmissão da mensagem pretendida e captara atenção do visitante, possibilitando uma nova visão do objeto museológico" (MACHADO, s/d, p.1541). Em síntese, a tecnologia pode auxiliar os museus a constituir "um espaço atrativo com capacidade para alargar e multiplicar as experiências sensoriais e cognitivas que cada sujeito pode usufruir". (MACHADO, s/d, p.1541)

Comment assurer la conservation de ce patrimoine immatériel? Plataformes instables, technologies en constant evolution et priorités d'investissement changentes: voilà les nouvelles norms du secteur des medias d'aujourd'hui. Alorsque les regards se tournent vers la prochaine innovation important, des jeux et oeuvres d'art numériques, des grands reportages interactifs et des webdocumentaires produits il y a à peine cinq ans sont confrontés à l'obsolenscense ${ }^{2}$. (Conferénce: comment assurer la pérennité das nouvelles formes de documentaires?)
Junto às plataformas reconhecidas pela expressão cross-media, destacam-se de forma crescente os lançamentos de webdocumentários, um meio plausível de se expandir o conhecimento a algo que ainda não seja tema físico de um museu por exemplo.

Pelo neologismo webdocumentário designamos um documentário cuja concepção e realização é feita para a web e que é difundido pela web. Não se trata de um documentário no formato televisivo ou cinematográfico de narração linear, que encontra na internet um enésimo espaço de difusão, mas um tipo de prolongamento do que foram os CD-ROMs ou DVD-ROMs: uma obra que utiliza as tecnologias da web e seus diferentes recursos multimídias. (...) O modo de narração dos webdocumentários é concebido de maneira que o leitor/espectador navegue pela interface de forma totalmente de linearizada. É ele quem conceberá de maneira única seu percurso pelo webdocumentário ${ }^{3}$. (CROU, 2010)

Essa é uma das premissas do documentário interativo EntreVilas ${ }^{4}$ : permitir ao usuário percorrer as camadas históricas e contemporâneas das vilas operárias da cidade de São Paulo, revelando tanto seus relatos históricos, quanto a sua atual conformação, características narradas por alguns de seus moradores.

Este percurso narrativo permite construir de forma lúdica, a descrição de parte dos processos envolvidos em meio à conformação econômica, social e espacial da cidade de São Paulo, uma 


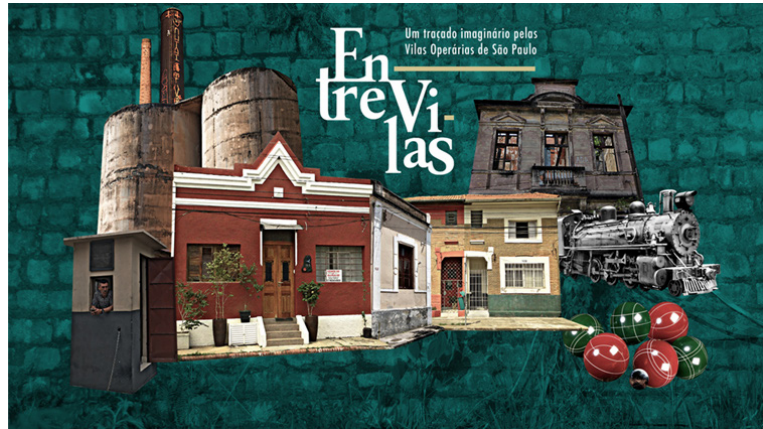

Figura 1. Interface inicial do webdocumentário EntreVilas. A plataforma pode ser acessada pelo endereço: http://entrevilasdoc.com.br/. Layout gráfico executado por Caio Dutra, 2018

5. "As cidades tombadas assinalavam o momento de construção da brasilidade como forma de ser, viver e construir, e funcionavam, ainda, como testemunhos vivos desse momento, destinados a propiciar aos cidadãos brasileiros o entendimento da formação da sua própria cultura, arte e história". (SANT'ANNA, s/d, p.140-141). Ao considerarmos que nem todos os ambientes urbanos podem ser preservados de forma intocável, por inúmeros fatores, a utilização de meios virtuais para o registro e imersão dos visitantes a um contexto narrando as transições de determinado ambiente urbano,

pode também ser visto como um meio viável.

6. Deve-se ressaltar que ao mesmo tempo em que a não linearidade fixada pela plataforma pode ao mesmo tempo incentivar e desorientar o usuário da plataforma para evitar problemas com a continuidade da navegação do enredo proposto, devem ser estabelecidos os devidos cuidados em meio à construção narrativa, pesquisa, dimensionamento de textos, gráficos, vídeos, imagens e ilustrações propostas, interface e recursos disponibilizados pela plataforma, entre outras características. vez que o projeto discute as relações entre trabalho, moradia e memória, registrando o contexto em que essas localidades foram construídas, bem como sua relevância ao longo do processo de expansão urbana (Figura 1).

Desta forma, podemos considerar que a elaboração de webdocumentários abordando temáticas culturais se apresenta como uma ferramenta importante para o registro e a descrição de ambientes caracterizados em meio à "cidade patrimônio"5, um contexto que no Brasil surge com o intuito de suprir a histórica carência educativa e forte demanda política dos anos 1930, buscando a afirmação de uma identidade nacional e construção de uma ideia de arte da arquitetura brasileira.
Uma espécie de reflexo decorrente da maior circulação de conhecimentos e respectiva facilidade de acesso aos equipamentos, onde a criação e registro documental em paralelo à facilidade de divulgação auxiliam um número crescente de autores e realizadores a colocar em prática seus projetos, exibidos cada vez mais em ambientes que agora extrapolam os tradicionais e limitados espaços de cinema e televisão. (BAUER, s/d) Avanços que assim como as tecnologias anteriores avançam em paralelo ao crescimento de acessos de usuários de distintas origens étnicas, sociais e de padrões econômicos. (OBSERVATOIRE DU DOCUMENTAIRE, 2011)
Um contexto capaz de promover narrativas onde a sobreposição de ambientes históricos e sua navegação cinematográfica permitem a articulação de diferentes públicos e abordagens, livremente delineadas pelos usuários interessados na interatividade presente nas plataformas conforme $o$ convite oferecido pelo enredo proposto ${ }^{6}$.

A sobreposição de ambientes históricos, vistos a partir de uma navegação cinematográfica de distintas abordagens narrativas, permite a atração de diferentes públicos. Neste ambiente virtual, o usuário torna-se responsável pelo delineamento do percurso que deseja traçar para obter o conhecimento proposto, uma ação não permitida pelos documentários, cuja linearidade do enredo não pode ser alterada pelo espectador.

Ainda pouco difundidos no Brasil, os webdocumentários são muito utilizados para sensibilização em questões que envolvam mobilizações sociais. Ao analisarmos sua estrutura tais produtos revelam um imenso potencial quando aplicado entre as temáticas de valorização patrimonial, principalmente quando relacionadas ao contexto urbano, possibilitando assim a reinserção do monumento ao seu ambiente, muitas vezes esquecido, em reflexo dos efêmeros processos de especulação, capazes de aniquilar a trajetória de remanescentes históricos, sobretudo os de caráter industrial. 
7. CPF -Centro de Pesquisa e Formação. SESC - Serviço Social do Comércio.

8. <http://estudiocrua.com. br/> acesso em: mar. 2019.
A utilização de webdocumentários em meio à valorização de remanescentes do patrimônio industrial, vistos a partir de suas vertentes materiais e imateriais.

Considerando que as linguagens de webdocumentários ainda são pouco difundidas no Brasil (e em diversos países como um todo), foram produzidas ao longo de três meses, narrativas documentais interativas, focadas principalmente na sensibilização e mobilização de moradores das principais vilas operárias remanescentes na cidade de São Paulo.

EntreVilas, se caracteriza como um projeto coletivo, lançado inicialmente como um laboratório de cartografias da memória, coordenado pelo CPF $\mathrm{SESC}^{7}$ e dirigido pelo Estúdio $\mathrm{Crua}^{8}$, cuja temática foi inicialmente estruturada pelo delineamento das Vilas Operárias de São Paulo. Uma trajetória que ao longo de seu processo criativo foi capaz de revelar seu potencial quando aplicadas entre as questões de valorização, relacionadas ao contexto urbano surgido em processos efêmeros de especulação, capazes de aniquilar a trajetória de remanescentes industriais.

\section{Vilas Operárias e a conformação do contexto capital $x$ moradia.}

Antes de qualquer coisa é necessário compreendermos o que é uma Vila Operária e como esta estrutura se insere em meio ao contexto de ex- pansão industrial e urbana de determinada região, considerando neste processo suas inúmeras variáveis de acordo com os ambientes em que se instalam.

Com a Revolução Industrial, a produção artesanal perde cada vez mais espaço para a mecanização dos processos produtivos, levando para as cidades ou determinadas regiões suburbanas (ambiente de instalação das indústrias), um contingente crescente de operários. Neste processo, as instalações pré-existentes por muitas vezes não conseguem suprir as demandas geradas em função deste "novo personagem". As vilas operárias viriam então suprir parte desta carência.

É nessa ótica que surgem, em 1822, as propostas do filósofo francês Charles Fourier, cujo principal emblema é o Palácio Societário ou Falanstério, concebido como um grande edifício onde, além das habitações para três mil e quinhentas pessoas, alguns equipamentos de uso coletivo complementariam a vida doméstica comunitária. (TRAMONTANO, 1998, p.22)

Tais conjuntos possuem como característica o vínculo com alguma unidade industrial. Em seu programa poderiam reunir residências, escolas, igrejas, armazéns, cinemas, teatros, espaços de recreação, unidades de assistência médica e social. Características variáveis conforme os interesses dos industriais envolvidos e suporte das necessidades dos operários. 
9. Um fator importante ao considerarmos o potencial técnico e tecnológico em que o Brasil estava inserido em meados do século XIX, um contexto ainda marcado pela forte atuação de profissionais estrangeiros e pela capacitação profissional brasileira nos grandes centros europeus. Características que revelam inúmeras influências europeias na conformação urbana de então.

10. Esta colocação é válida uma vez que o processo de industrialização da cidade de São Paulo ocorre em paralelo ao seu processo de urbanização e adensamento populacional. Se por um lado os industriais buscavam reunir trabalhadores para a atuação em suas unidades industriais, nos "subúrbios"

paulistanos, observam a necessidade de articular moradias aos funcionários, sobretudo quando suas funções eram vistas como fundamentais para o funcionamento da fábrica. Por outro lado, empresários interessados no aumento de suas rendas, solicitavam autorizações para a construção de edificação de vilas, com o intuito de abrigar a classe operária e aniquilar os cortiços que "assombravam" a cidade.

11. Uma estrutura semelhante com o atual propósito de articulação de moradias populares exercido nos dias de hoje, tendo como diferencial o rompimento do vínculo com os empresários industriais e sua vinculação com o Estado.

usjt • arq.urb • número 24 | janeiro - abril de 2019
Interessante ressaltar também, o fato de que em muitos casos tais vilas operárias possuem seu projeto construtivo e urbano associado a engenheiros, técnicos ou arquitetos, com o intuito de aplicar as novas normas higiênicas impostas com o crescimento social e urbano, decorrentes do processo de industrialização. ${ }^{9}$

A conformação de Vilas Operárias torna-se comum ao longo dos séculos XIX e XX, sendo em alguns casos ainda aplicada por determinadas indústrias. No Brasil, tal prática foi intensificada entre a segunda metade do século XIX e final do $X X$, inicialmente com a criação de vilas operárias em localidades rurais (associadas aos engenhos de cana, fazendas de café, extração de minerais) e núcleos fabris de centros urbanos. Ao final do século $X X$, estes modelos entraram em colapso, reflexo da aplicação de novos programas de habitações de caráter social, necessidade de modernização das plantas industriais, transições de ciclos econômicos entre outras características.

[...] muitas empresas criaram não só vilas, mas verdadeiras cidadelas, porque se estabeleciam em locais isolados, onde inexistia mercado de trabalho ou cidades capazes de concentrar trabalhadores e oferecer o mínimo de serviços e equipamentos urbanos. (BONDUKI, 1998, p.47)

Conforme o relato de Blay (1985), a Vila Operária, ou casa na vila operária, constitui o elemento mediador entre a venda da força de trabalho e o respectivo preço que deveria ser pago por esta força. Neste sentido, quando a casa é ofertada ao trabalhador ela passa a interferir nas relações de produção, uma vez que passa a oferecer, ao lado do valor do uso, um valor de troca. A casa se torna uma mercadoria, e nesta transação o operário entra como o "comprador", possuidor de dinheiro e o proprietário (industrial) como o personagem que a subloca.

Entre os fatores capazes de problematizar o vínculo entre moradia operária $x$ empregador, podemos destacar que na maioria dos casos, tanto o empregador quanto o proprietário, representam o mesmo indivíduo ${ }^{10}$, proporcionando em alguns casos a possibilidade de práticas abusivas. O capital responsável pelo financiamento de tais moradias seria originário dos excedentes do próprio trabalho dos operários que ainda pagariam pela sua utilização ao longo de seu vínculo com a empresa. ${ }^{11}$

Neste processo, os empreendedores industriais poderiam por um lado, manter os salários baixos e ainda "oferecer" tais casas a um preço mais baixo aos trabalhadores. A justificativa da fixação de valores abaixo do mercado encontrava nesta "parceria" importante aliado. Os industriais defendiam também que com esta prática, os excedentes oriundos do pagamento deste vínculo, poderiam ser reinvestidos em melhorias das casas, equipamentos, produção e maquinário, oferecendo benefícios ao trabalhador; ou manter os salários baixos e elevar os aluguéis, exercendo assim uma prática mais abusiva (caracterizando a acumulação do capital baseada na mais-valia). (BLAY, 1985) 
12. Que viria seu fim com a demolição do conjunto habitacional Pruitt-Igoe, (St. Louis, Missouri - EUA) em 1973.
Em síntese, ao serem inseridas ao contexto do desenvolvimento, as vilas operárias passam a interferir nas relações estabelecidas entre operário $x$ patrão a partir do momento em que estas se tornam "parte" do salário operário, ou o preço de parte da força de trabalho, ou o custo necessário para se conservar o operário como tal, permitindo que este impulsione a produção. (MARX, apud: BLAY, 1985)

As relações paternalistas entre indústrias e moradias são rompidas de forma gradual, a partir do momento em que as fábricas passam a produzir utensílios para o consumo das massas. Os ideais modernistas atuam de forma marcante na racionalização deste processo, a arquitetura e o urbanismo se revestem com o viés da lógica industrial ${ }^{12}$, cuja diversificação, aliada ao processo de urbanização, retira das mãos dos industriais a função da subsistência residencial, que passa a ser de responsabilidade do Estado ou determinados empreendedores imobiliários.

[...] o operário-inquilino é o portador da história oral que permite recompor a trajetória habitacional de parcela do operariado das vilas. Sobretudo os antigos moradores podem dar, e deram a visão de que o operário tinha da casa. Por outro lado, a recuperação das origens da habitação do trabalhador urbano se mescla com toda a complexidade dos movimentos político-ideológicos do começo do século. A participação do trabalhador no sistema capitalista se fez inevitavelmente de forma contraditória. (BLAY, 1985)

\section{O despontar econômico da cidade de São Paulo:}

Ao relacionarmos a conformação entre vilas operárias e o desenvolvimento industrial na cidade de São Paulo, devemos ter em mente que até o século XVIII, pouco se conhece sobre a expansão industrial do Estado de São Paulo, entretanto, a localidade sempre foi vista com destaque quando relacionada à distribuição de caminhos. A então província assumia papel secundário nas relações econômicas impostas por Portugal, buscando promover a comunicação entre o interior do Brasil e seu litoral. Para isso era traçado um caminho pelo Vale do Paraíba, porém este não chega a representar importância neste primeiro momento, uma vez que "para as comunicações do Rio de Janeiro com São Paulo preferia-se geralmente a via marítima, através de Santos." (MATOS, 1974, p.30)

Com o passar dos anos, partiam de seu território caminhos para "a vila da Constituição (atual Piracicaba): (...), passando por Itu e Porto Feliz, de onde tinha início a navegação do Tietê; para Franca: passando por Jundiaí, Campinas, Mogi-Mirim, Casa Bragança e Batatais, (...); para a divisa de Minas Gerais: passando por Juqueri, Atibaia e Bragança, (...); para o chamado "Norte de São Paulo": passando por Mogi das Cruzes, Jacareí, São José dos Campos, Taubaté, Pindamonhangaba, Guaratinguetá, Lorena, Areias, indo até Bananal, (...); para Ubatuba, por Santos, 
São Sebastião e Caraguatatuba, (...); de Santos a Iguape, passando por Itanhaém; em direção ao Paraná: através de Cotia, São Roque, Sorocaba, Itapetininga e Faxina (atualmente Itapeva)." (PINTO, 1903, p.19)

Em acréscimo a estas vias "locais", existiam também os caminhos que buscavam a articulação com os atuais Estados do Paraná (caminho do Vicimão/Peabiru), Mato Grosso (Monções de Cuiabá), Goiás (caminho dos Goiases), Rio de Janeiro e Minas Gerais (trajetos do Vale do Paraíba). (BRUNO, s/d)

Discute-se que no início do século XIX, o complexo do café impulsiona a indústria por meio do beneficiamento dos produtos colhidos nas lavouras ou em seu suporte. (MILLIET, 1938) Na segunda metade do século XIX, o ideal: cidade $x$ ferrovia $x$ indústria ganha forças com a instalação da São Paulo Railway Company, permitindo a comunicação entre as novas áreas de cultivo de café (em pleno avanço na região do Planalto) e seu transporte até o porto de Santos. Desta forma, São Paulo se solidifica como importante entreposto comercial, sendo pouco a pouco consolidado como um dos principais pontos de dispersão de produtos industrializados e negócios do país. (MATOS, s/d)

A proclamação da Independência abriria novas possibilidades. Para PRADO Jr. (1976, p.196) "o Brasil realizara um grande avanço no sistema de transportes, e apesar de suas deficiências (como em particular a desconexão das linhas e falta de um plano geral e de conjunto), terá lançado as bases de todo seu desenvolvimento futuro." O mesmo autor destaca ainda que "em termos relativos, o progresso no período que ora nos ocupa será mais acelerado que em qualquer outro momento posterior."

Em São Paulo, o trinômio: cidade $x$ ferrovia $x$ indústria, faz com que a composição urbana da cidade comece a ser alterada. Bairros como o Brás, Bexiga, Barra Funda, Lapa e Mooca, protagonizam este cenário, com a abertura de diversas indústrias, processo este atrelado ao desenvolvimento de vilas operárias.

As áreas industriais caracterizavam-se assim, pelas centenas de casas enfileiradas diretamente sobre as calçadas ou no interior das quadras, pelas pequenas oficinas ou fabriquetas ao longo dos quarteirões, pelos armazéns comerciais nos principais cruzamentos viários, destacando-se apenas em sua paisagem urbana, as grandes fábricas e suas chaminés. (BENCLOWICZ, 1989, p.246)

Em decorrência do processo de industrialização e do consequente inchaço populacional dos centros urbanos, industriais ou "empreendedores imobiliários" passam a receber incentivos para a edificação de vilas buscando a reversão dos problemas decorrentes do desenfreado crescimento de cortiços. Tais conjuntos residenciais pontuariam as novas regiões recentemente loteadas si- 


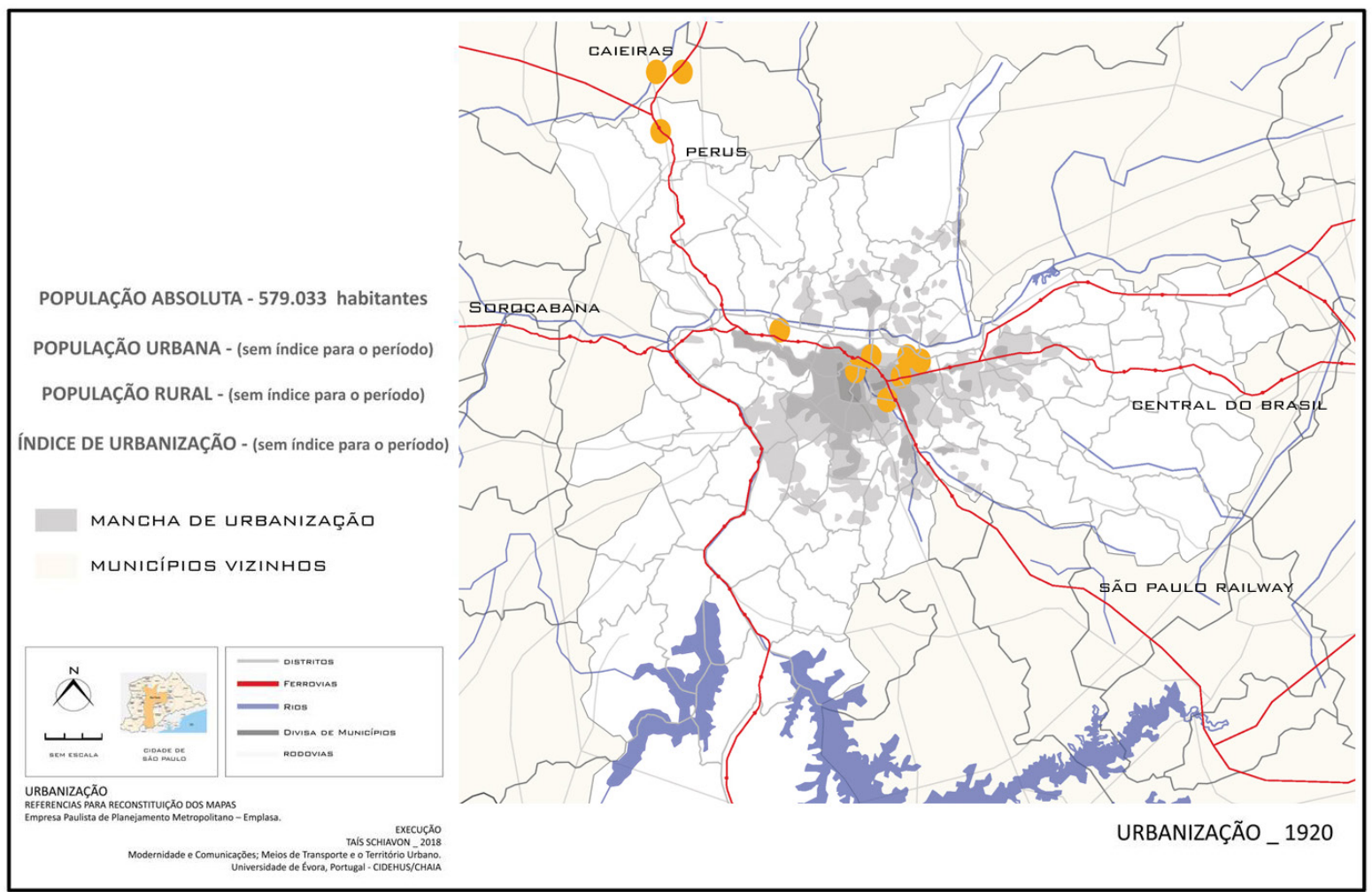

Figura 2. Mancha do adensamento urbano paulistano em meados dos anos 1920 e posicionamento das fábricas e vilas abordadas pela pesquisa (para identificação das indústrias demarcadas em amarelo, vide figura 7). Fonte: Execução da autora conforme dados da pesquisa.

\begin{tabular}{|l|c|c|c|c|c|c|}
\hline \multicolumn{7}{|c|}{ DADOS INDUSTRIAIS DO ESTADO DE SÃO PAULO } \\
\hline & \multicolumn{3}{|c|}{ ESTABELECIMENTOS } & \multicolumn{3}{c|}{ OPERÁRIOS } \\
\hline & 1907 & 1912 & 1920 & 1907 & 1912 & 1920 \\
\hline SÃO PAULO & 326 & 3.321 & 4.157 & 24.168 & 42.843 & 85.466 \\
\hline$\%\left(^{*}\right)$ & 10,2 & 35,1 & 30,6 & 16,2 & 29,6 & 29,1 \\
\hline
\end{tabular}

Figura 3. Tabela de dados Industriais do Estado de São Paulo. FONTE: Censo Industrial de 1907; Recenseamento Geral, 1920, p.08; Inquérito Industrial, 1912, p.170. Considerando valores de todos os Estados brasileiros dos respectivos períodos. tuadas próximas aos eixos férreos, leitos de rios ou pontos estratégicos de extração de matéria-prima. (DEAN, s/d, p.12)

A situação mais conveniente para as vilas operárias deve ser, sem dúvida, aquela que reúna a facilidade de comunicação à barateza dos terrenos que devem ser amplos bem como as vantagens de um abastecimento regular. Em torno da cidade de São Paulo, num raio de $10 \mathrm{a}$ 15 quilômetros não faltam lugares preenchendo estes requisitos (...). (Governo de São Paulo, apud: BLAY, 1985, p.73)

Ao dividirmos o processo de industrialização da cidade de São Paulo em períodos, devemos inicialmente considerar o arco temporal atuante entre o final do século XIX e o início da década de 1930. Nesse momento, a relação existente entre fábricas, cursos d'água, fontes de matéria-prima e terrenos planos é fundamental para a estruturação da cidade. (LANGENBUCH, 1971)

De um modo em geral, o posicionamento industrial é concentrado em áreas extensas situadas além do centro original, o que leva a conformação dos bairros industriais do Brás, Mooca, Belenzinho, Água Branca e Lapa, salvo algumas funções industriais que carecem de matéria prima proveniente de regiões externas à cidade de São Paulo, como as unidades industriais de Caieiras e Perus (Figuras 2 e 3). 
Durante a década de 1920 entraram em São Paulo, vindas da Europa, maiores quantidades de imigrantes dos que as chegadas nos quinze anos anteriores e, quando se desencorajou a imigração na década de 1930, essas quantidades foram substituídas por um fluxo ainda maior proveniente do setor agrícola e dos outros Estados. A antiga cidade de adobe se caracteriza agora pelos arranha-céus, largas avenidas e o ideal "metropolitano", nasceria deste processo, a "Chicago Latino-Americana". (LIMENA, 1996, p.80-81)

Os empresários paulistas suplementavam a remuneração inferior dos trabalhadores com vários "benefícios". Ao considerarmos a baixa densidade urbana (sobretudo em relação ao contexto estabelecido até 1920), a localização "suburbana" de boa parte das plantas industriais, o alto valor de aluguéis e a existência de um número insuficiente de casas disponíveis, percebemos a origem do vicioso jogo de interesses.

Inúmeros foram os conflitos entre operários e industriais. $\mathrm{O}$ anarquismo foi o movimento mais atuante nas primeiras décadas da urbanização paulistana, quando se deu o grande surto de construção das vilas operárias. Os ideólogos destas correntes, e os que atuaram conforme seus princípios deixaram suas marcas nos jornais operários. Para Blay (1985), é do significado atribuído a casa, nas relações de produção, que decorrem as orientações políticas assumidas na luta entre patrões e empregados.

Dentre os movimentos de destaque deste período, merece menção a greve de 1917, organizado por operários e comerciantes de São Paulo, insatisfeitos com as condições de trabalho e os baixos salários pagos na época, após cinco dias de paralisações e movimentos nas ruas, as reivindicações dos grevistas foram atendidas.

Em acréscimo às greves, os reflexos da Revolução Paulista (1924), o desmoronamento do comércio internacional em 1929 (ainda fortemente relacionado ao café) e a Revolução Constitucionalista (1932) quase paralisaram as indústrias de São Paulo. Para Dean (s/d, p.197), a partir de então, "o futuro do Brasil dependia da exploração do minério de Minas." Nesta transição das bases produtivas, os paulistas principiaram a manufaturar materiais e motores elétricos, máquinas têxteis, equipamentos para a indústria, peças de automóveis, acessórios, ferramentas, implementos agrícolas, aparelhos de gás, relógios, balanças, e tecidos de rayon. O Estado Novo abriu novas e extensas fontes de financiamento público.

Em meados do século $X X$ um novo conjunto de fatores políticos, econômicos e sociais inicia uma espécie de transição destes antigos padrões. A imposição da lógica automobilista, com a disseminação de avenidas, automóveis e caminhões 


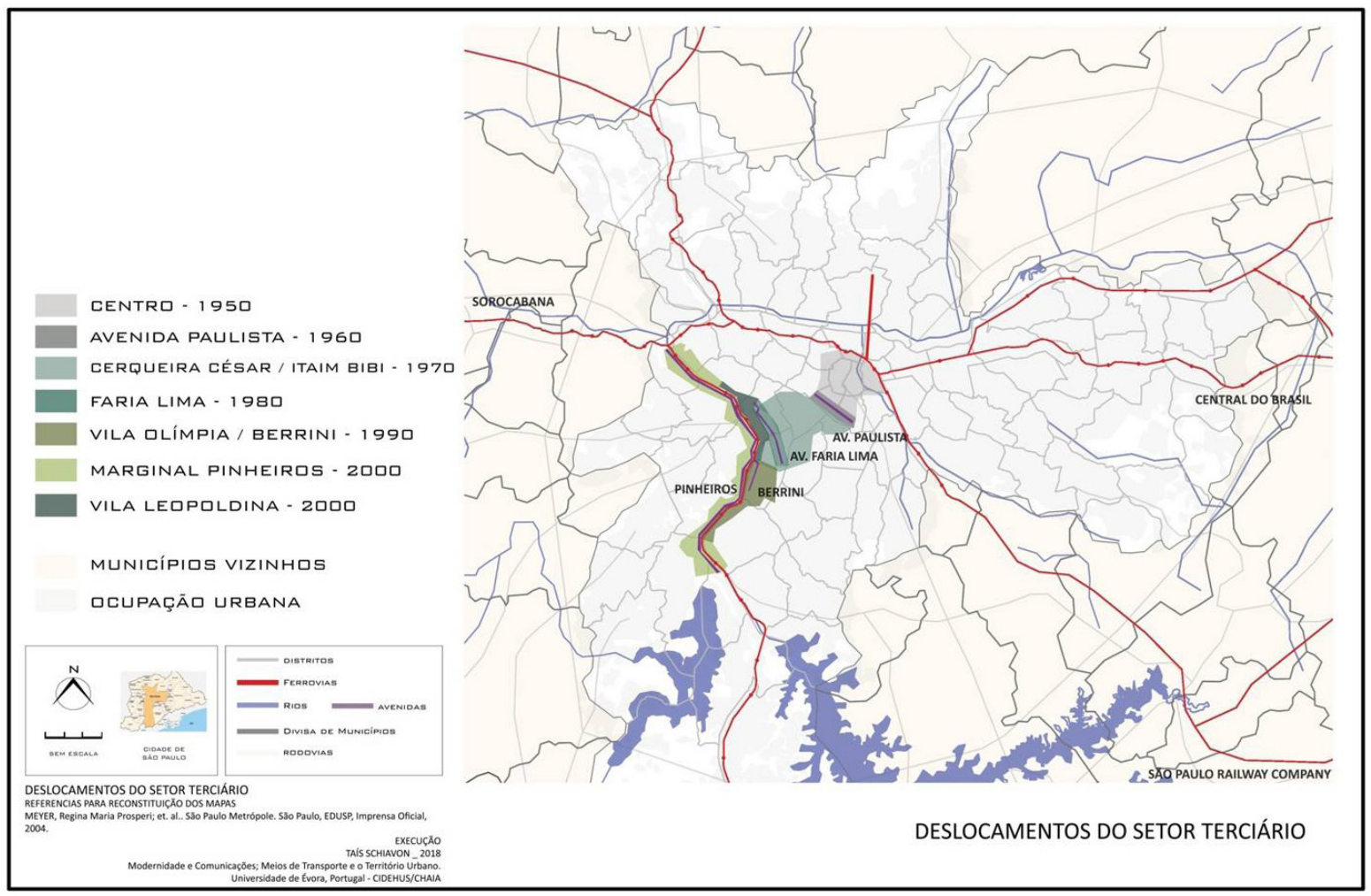

Figura 4. Vetor de expansão do setor terciário na cidade de São Paulo. O processo que teve seu início impulsionado pela expansão das atividades econômicas da região central, se desloca cada vez mais em direção aos limites impostos pelas Marginais Pinheiros e Tietê. Fonte: execução da autora conforme informações contidas em: MEYER; et.al., 2004.

13. É válido citar neste ponto, que atualmente, indícios demonstram o início do processo de desmonte das plantas industriais de região metropolitana de São Paulo,

o que demonstra que o fenômeno tende a se deslocar. impulsiona o desenvolvimento industrial ao longo das marginais Pinheiros e Tietê. Os eixos ferroviários ainda exercem influência em meio ao processo de industrialização, entretanto seus domínios passam a ser mais atuantes em direção aos municípios que conformariam a Região Metropolitana de São Paulo. ${ }^{13}$

O setor terciário ganha destaque na capital, impulsionando o deslocamento industrial para as cidades próximas. Em reflexo, a paisagem urbana anteriormente marcada pelas unidades fabris dotadas de chaminés e imensos galpões de tijolos e ferro fundido, abre espaço para um novo processo de reconfiguração, pautado agora pela verticalização desenfreada, e disseminação de complexos comerciais compostas por torres empresariais e lojas de hipermercados, apagando progressivamente os remanescentes da atividade fabril (Figura 4).

A partir deste momento, o abandono e a degradação encontram na especulação imobiliária o combustível perfeito para este novo processo de reformulação. São deste período os primeiros estudos de tombamento dos remanescentes industriais da cidade de São Paulo. Vale aqui destacar que deste processo inúmeros foram os conflitos entre as esferas públicas e privadas. Entre os resultados podem ser identificados desde diferentes práticas de gestão, valorização e manutenção do patrimônio industrial e urbano, até os exemplos de sua completa destruição. 


\section{O contexto da vila operária no Brasil: os exem- plares da cidade de São Paulo.}

Quando comparado ao contexto europeu, o contexto brasileiro demonstra algumas semelhanças em relação ao sentido da casa em meio às relações de produção, estruturação política e social, um reflexo da lógica do capital. (ENGELS, apud: BLAY, 1985) Entretanto, em reflexo da diversidade das considerações históricas e ambientais brasileiras, os modelos de Vilas Operárias aplicadas no Brasil, encontram em meio às peculiaridades econômicas e ambientais locais, elementos capazes de diferenciar tais práticas, desta forma, o problema habitacional (tanto em início do século XX quanto atualmente) não pode ser visto meramente como um problema operário, mas sim uma questão social, política e econômica.

No Brasil, a moradia na forma das vilas operárias encontra suas raízes em um remoto passado. Conforme os estudos de Correia (2004) elas aparecem como um sucedâneo da senzala, ocorrendo junto à propriedade rural açucareira e cafeeira, onde sobre a proteção dos olhos da casa senhorial eram edificados conjuntos para os negros, as senzalas, tipologia habitacional escravocrata. Conformação esta, que com o sistema do colonato assume a forma de colônias, atraindo um grande número de imigrantes imbuídos da missão de "construir a América". A partir deste momento, as primeiras vilas operárias brasileiras, ainda fortemente vinculadas à transformação de matérias primas de caráter primário, teriam em finais do século XIX feições e posicionamentos semelhantes aos das colônias herdadas das fazendas de cana e café.

Ao longo do tempo o vínculo moradia $x$ empregador foi sendo cada vez mais enfraquecido, agravando ainda mais o déficit habitacional de grandes centros urbanos, cujo ápice pode ser compreendido por meio da análise da explosão de cortiços em meio aos centros urbanos. Vale ressaltar que ainda hoje as moradias populares continuam a ser posicionadas nos subúrbios desprovidos de equipamentos e comunicação com os centros econômicos, uma herança das normatizações sanitárias de fins do século XIX que previam que unidades industriais e suas respectivas residências deveriam se situar fora dos limites urbanos, proporcionando assim os novos ideais de modernização e higienização.

Conforme estabelecido no Código Sanitário (1894), as edificações que fossem destinadas, de forma permanente, a um grande número de habitantes, assim como aquelas destinadas à habitação das classes pobres, e as vilas operárias, deveriam ser edificadas fora da aglomeração urbana. Sendo de preferência utilizados terrenos nos subúrbios, afastados em torno de 10 a 15 $\mathrm{km}$ da cidade, em locais onde houvesse acesso 
14. Tal ação reforçaria ao longo dos anos ainda mais o vínculo entre ferrovias, desenvolvimento industrial e expansão do processo de urbanização. Se em seu princípio as ferrovias serviram apenas como eixo de transporte de mercadorias e passageiros a longas distâncias, com o tempo, o modal desenvolveria também o serviço de transportes de passageiros, que moravam nos centros urbanos e trabalhavam nos subúrbios industriais. Deve ser ressaltado também o potencial de articulação urbana atrelado à instalação de estações em áreas mais distantes do núcleo urbano. Em função de carências de abastecimento dos funcionários das estações, uma atividade comercial e de aglomeração urbana é atraída para os pontos até então isolados, configurando assim os "subúrbios estações" definidos por Langenbuch (1971) por meio de rede ferroviária, mesmo que fossem necessários investimentos, por parte do poder público, para ampliação deste meio de transporte. ${ }^{14}$ (CORDEIRO, 2010) "As vilas operarias deverão ser estabelecidas fora da aglomeração

urbana" (Código Sanitário, Capítulo V, 1894), o que no caso da cidade de São Paulo pode ser visto como uma das maneiras de se expandir os primeiros limites definidos no Padrão Municipal (Figuras 5 e 6 ).

\begin{tabular}{|c|c|c|c|c|c|}
\hline \multicolumn{6}{|c|}{ MUNICÍPIO DE SÃO PAULO } \\
\hline DATA & População absoluta & Taxa de Crescimento 2 & População Urbana & População Rural & Grau de urbanização (\%) \\
\hline \multirow[t]{2}{*}{1872} & 31.385 & & - & - & - \\
\hline & & 4,1 & & & \\
\hline \multirow[t]{2}{*}{1890} & 64.934 & & - & - & - \\
\hline & & 14,0 & & & \\
\hline \multirow[t]{2}{*}{1900} & 239.820 & & - & - & - \\
\hline & & 4,5 & . & & \\
\hline \multirow[t]{2}{*}{1920} & 579.033 & & - & - & - \\
\hline & & 4,2 & & & \\
\hline \multirow[t]{2}{*}{1940} & 1.326 .261 & & 1.258 .482 & 67.779 & 94,9 \\
\hline & & 5,2 & & & \\
\hline \multirow[t]{2}{*}{1950} & 2.198 .096 & & 2.052 .142 & 145.954 & 93,4 \\
\hline & & 5,6 & & & \\
\hline \multirow[t]{2}{*}{$1960^{\star \star}$} & 3.781 .446 & & -1 & -1 & -1 \\
\hline & & 4,6 & & & \\
\hline \multirow[t]{2}{*}{1970} & 5.924 .615 & & 5.872 .856 & 51.759 & 99,1 \\
\hline & & 3,7 & & & \\
\hline \multirow[t]{2}{*}{1980} & 8.493 .226 & & 8.337 .241 & 155.985 & 98,2 \\
\hline & & 1,2 & & & \\
\hline \multirow[t]{2}{*}{1991} & 9.646 .615 & & 9.412 .894 & 233.291 & 97,6 \\
\hline & & 0,9 & & & \\
\hline \multirow[t]{2}{*}{2000} & 10.435 .252 & & 98.13 .187 & 621.065 & 94,0 \\
\hline & & 0,8 & & & \\
\hline 2010 & 11.253 .503 & & 11.152 .344 & 101.159 & 99,1 \\
\hline
\end{tabular}

Figura 5. Tabela de Município de São Paulo. Considera os anos de desenvolvimento dos recenseamentos censitários promovidos pelo IBGE. Fonte: IBGE e EMPLASA, com elaboração SMDU/Dipro. * Referente aos domicílios regulares e permanentes/ ** Inclui os dados referentes à Osasco que se torna um município posteriormente à data do levantamento/1 Os dados do Censo de 1960 não permitem a identificação da população rural e urbana/2 Taxa de Crescimento Geométrico Anual. 


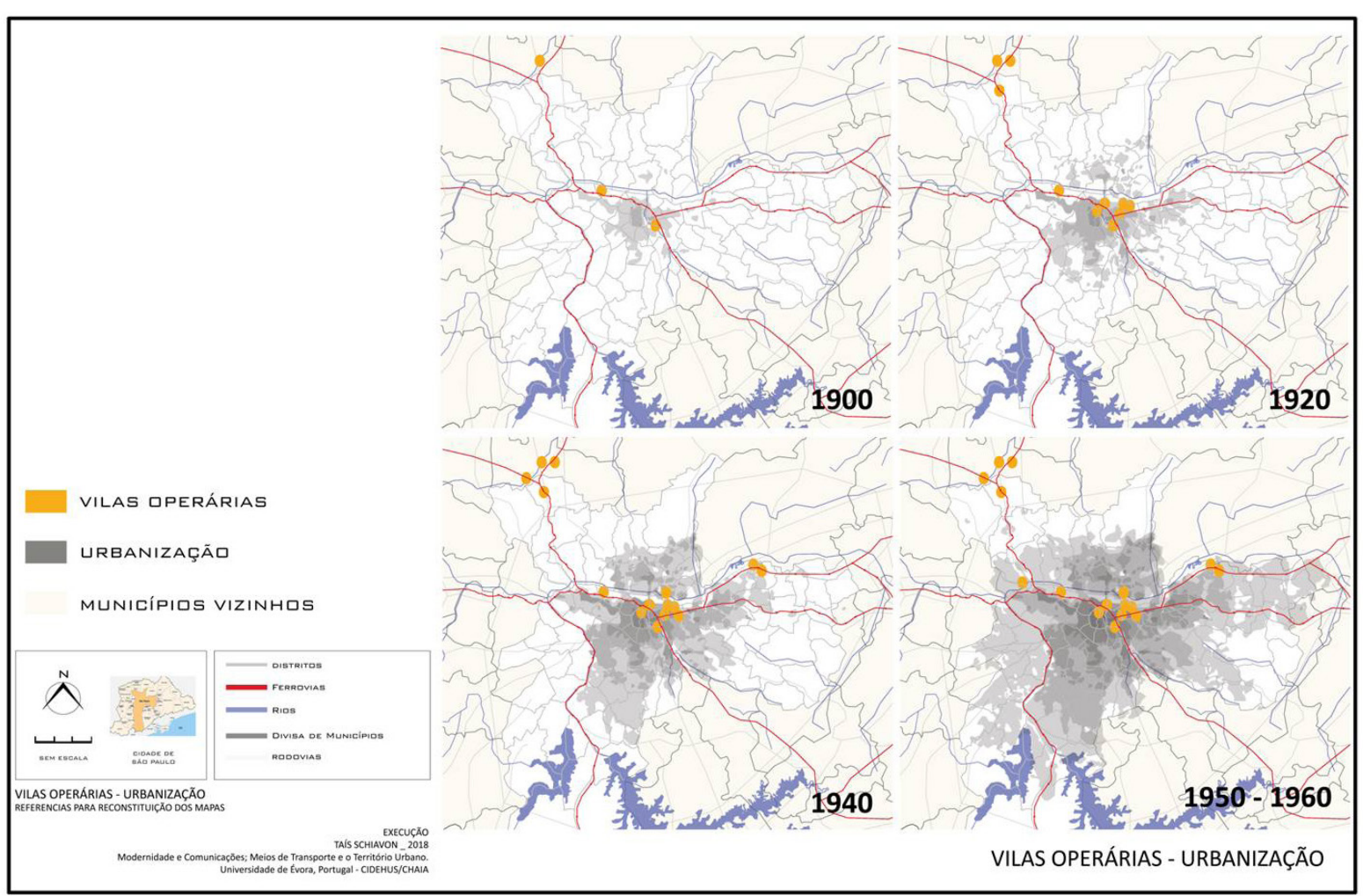

Figura 6. Manchas do adensamento urbano paulistano e posicionamento das fábricas e vilas abordadas. Fonte: Execução da autora conforme dados da pesquisa.

\section{As Vilas Operárias de São Paulo:}

A linearidade narrativa do documentário interativo foi construída a partir da cronologia existente entre a instalação de fábricas como: Cia. Cantareira de Esgotos $^{15}$ (1877), Vidraria Santa Marina (1892), Antarctica (1895), Cotonifício Crespi (1897), Indústrias Reunidas Fábricas Matarazzo (1911- Boyes, 1924 - Cerealina), Sociedade Mútua Economisadora ${ }^{16}$ (1913) / Moinho Santista (1935), Cia Nacional de Tecidos de Juta (1916), Cia. de Melhoramentos de São Paulo (1920), Cia. Brasileira Cimento Portland (1926), Nadir Figueiredo (1930), Nitro-Química (1940); que juntamente à conformação de suas vilas operárias constroem a narrativa da espacialização urbana da cidade de São Paulo.

Vale ressaltar, que na pesquisa foram também consideradas algumas das vilas operárias vinculadas ao funcionamento da São Paulo RaiIway Company. Entre os exemplos as vilas das estações de Perus, Caieiras e São Miguel Paulista, cujo comportamento pode ser compreendido como modelos dos equipamentos descritos como "subúrbios estações" por Langenbuch (1971), onde um pequeno conjunto de residências oferecia o suporte ao funcionamento da estação, situada fora do perímetro urbano paulistano de então. Além destas vilas, a pesquisa também considera a Vila dos Ingleses, cujas unidades habitacionais abrigavam os funcionários de maior patente da companhia Inglesa. (Figura 7)
15. Considerada aqui como "indústria" em decorrência do processo de extração, ainda rudimentar, da cal utilizada como matéria prima para diversos melhoramentos na cidade de São Paulo.
16. Quando citada com "s",

a palavra Economisadora

se escreve com " $z$ ") representa o período histórico

onde as propagandas da vila eram escritas desta maneira. Quando escrito de forma correta, o texto pontua o estado atual da vila. 
Tais Schiavon

EntreVilas. Um traçado imaginário pelas vilas operárias de São Paulo.

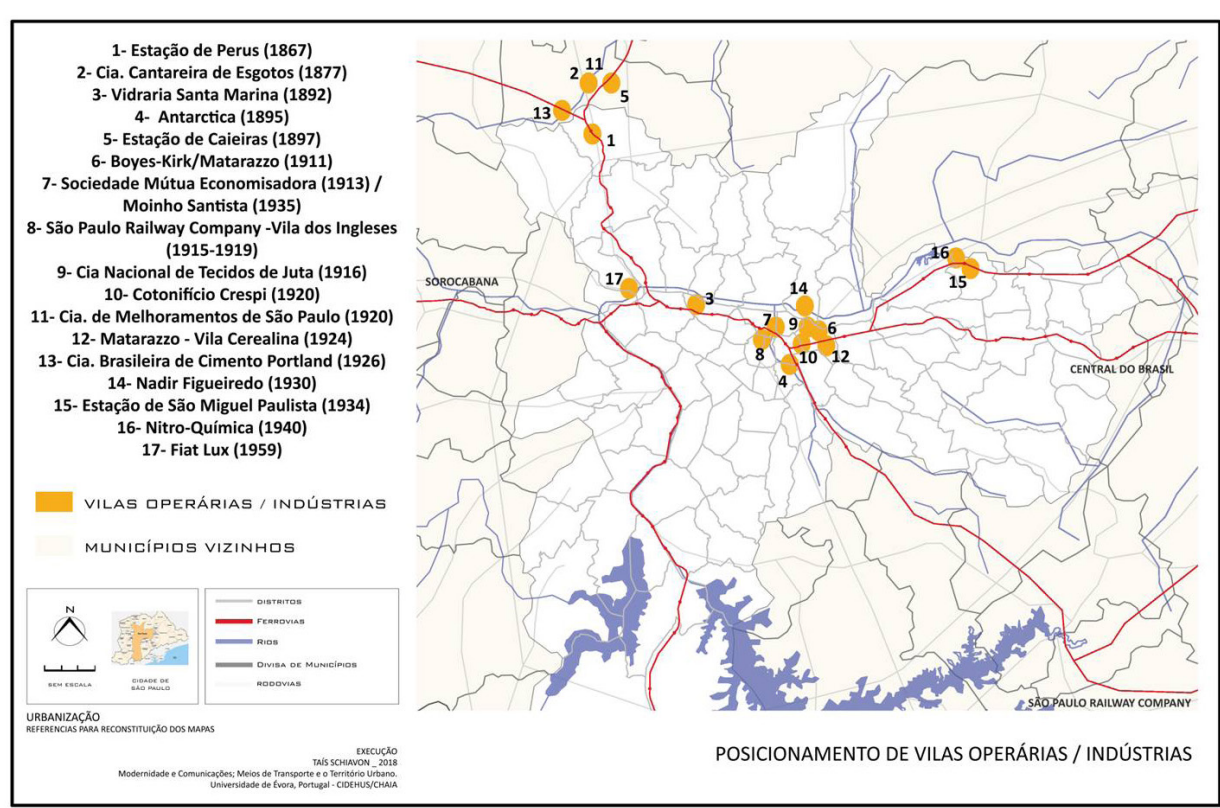

Figura 7. Identificação das Vilas catalogadas por este estudo. Fonte: Execução da autora conforme dados identificados na pesquisa.

\begin{tabular}{|c|c|c|c|}
\hline FÁBRICA & VILA & DATA/VILA & TOMBADA \\
\hline $\begin{array}{l}\text { Cia. Cantareira de } \\
\text { Esgotos }\end{array}$ & $\begin{array}{l}\text { Sem nome (originaria } \\
\text { Caieiras) }\end{array}$ & 1877 & -- \\
\hline $\begin{array}{l}\text { Vidraria Santa } \\
\text { Marina }\end{array}$ & $\begin{array}{c}\text { Vila Cia. Vidraria Santa } \\
\text { Marina }\end{array}$ & 1892 & Parte da fábrica \\
\hline Antarctica & Vila Antarctica & 1895 & Parte da fábrica \\
\hline $\begin{array}{l}\text { Boyes-Kirk/ } \\
\text { Matarazzo }\end{array}$ & Vila Boyes & 1911 & Fachada da vila \\
\hline $\begin{array}{l}\text { Sociedade Mútua } \\
\text { Economisadora } \\
\text { (1913) / Moinho } \\
\text { Santista (1935) }\end{array}$ & Vila Economisadora & 1913/1935 & Vila \\
\hline $\begin{array}{l}\text { São Paulo Railway } \\
\text { Company }\end{array}$ & $\begin{array}{c}\text { Vila Marquesa de Itu - } \\
\text { Vila Inglesa }\end{array}$ & 1915-1919 & Vila \\
\hline $\begin{array}{l}\text { Cia Nacional de } \\
\text { Tecidos de Juta }\end{array}$ & Vila Maria Zélia & 1916 & $\begin{array}{l}\text { Vila e parte da } \\
\text { fábrica }\end{array}$ \\
\hline Cotonifício Crespi & Vila Crespi & 1920 & $\begin{array}{l}\text { Parte da fábrica, } \\
\text { estádio e creche }\end{array}$ \\
\hline $\begin{array}{l}\text { Cia. de } \\
\text { Melhoramentos de } \\
\text { São Paulo }\end{array}$ & $\begin{array}{l}\text { Formação de bairros } \\
\text { (Caieiras) }\end{array}$ & 1920 & -- \\
\hline Matarazzo & Vila Cerealina & 1923-1924 & -- \\
\hline $\begin{array}{l}\text { Cia. Brasileira de } \\
\text { Cimento Portland }\end{array}$ & Vila Triângulo (PERUS) & 1926 & Parte da fábrica \\
\hline Nadir Figueiredo & $\begin{array}{c}\text { Conjunto Habitacional } \\
\text { Morvan Dias Nadir } \\
\text { Figueiredo } \\
\end{array}$ & 1930 & -- \\
\hline Nitro-Química & $\begin{array}{l}\text { Vila Americana / Vila } \\
\text { Nitroquímica }\end{array}$ & 1940 & Parte da fábrica \\
\hline Fiat Lux & Vila Fiat Lux & 1959 & -- \\
\hline
\end{tabular}

Figura 8. Tabela com a descrição e periodização das fábricas e suas respectivas Vilas Operárias na cidade de São Paulo. A periodização segue a cronologia de criação de Vilas Operárias. A tabela também demonstra se tais complexos são ou não tombados. Fonte: Execução da autora conforme pesquisa. 


\section{Cia Cantareira de Esgotos (1877)}

Após a constatação de minerais ricos em carbonato de cálcio, foram construídos dois fornos de barranco para produção da cal, as caieiras, que cederiam o nome à localidade.

Pouco tempo depois, a criação da Companhia Cantareira de Esgotos (1877) visava à extração dos recursos naturais de Caieiras para a prestação de serviços de higienização na capital. Num período onde a cidade de São Paulo iniciava sua expansão, a companhia seria a responsável pela produção de manilhas, ladrilhos, guias, sarjetas, tijolos e telhas, transportados em lombo de burro até a estação de Perus. (DONATO, 1990)

A crescente demanda produtiva da Companhia, aliada às dificuldades de transporte dos produtos até a estação de Perus, ponto mais próximo do escoamento dos produtos até a cidade de São Paulo, permite que em 1897 fosse aberta uma estação subsidiada a São Paulo Railway, originando assim, a estação de Caieiras. Considerando o posicionamento suburbano da região, além do armazém e plataforma da ferrovia, foi edificada uma pequena vila aos funcionários e engenheiros.

Entre os primeiros trabalhadores merecem destaque os imigrantes italianos. Para o abrigo dos operários foram edificadas inicialmente cerca de 180 residências. De acordo com Jerônymo (s/d), este núcleo pode ser identificado como um dos primeiros núcleos habitacionais edificado para trabalhadores livres no Brasil.

\section{Cia. Vidraria Santa Marina - Vila Velha / Vila Nova (1892)}

Em 1892 o Conselheiro Antônio da Silva Prado e o Dr. Elias Fausto Pacheco Jordão iniciaram a exploração de turfa com um forno primitivo em terrenos entre a Água Branca e a Freguesia do Ó, na várzea do Tietê, onde haviam sido descobertas jazidas de areia com cor e qualidade ideais para a manufatura de vidro branco. Pouco tempo depois, em 1896, a Vidraria Santa Marina seria fundada na região. (RODRIGUES, 2011)

Em função das dificuldades de acesso ocasionadas pela distância e principalmente pelas cheias do Tietê, foram construídas duas vilas operárias contíguas à fábrica: a primeira conhecida como Vila Velha, na década de 1910, e, mais tarde outra, conhecida como Vila Nova, em frente à área original. Aos poucos, a necessidade de habitações cresceu e ultrapassou os muros da empresa. (BRANDÃO, 1996, p.59)

Em 2009, alguns remanescentes isolados do complexo foram tombados pelo CONPRESP ${ }^{17}$, constituindo um interessante e raro caso na capital paulista, uma vez que ocorre no local a convivência entre bens tombados e a manutenção de uma atividade fabril. (RODRIGUES, 2011) Mesmo 
após inúmeras remodelações o complexo industrial ainda mantém a atividade vidreira, em 1960 foi incorporada ao grupo Saint-Gobain e em 2011 adquirida pela Nadir Figueiredo.

\section{Antarctica - Vila Antarctica (1895)}

Fundada em 1885 era inicialmente um abatedouro de suínos. Apenas em 1891 foi oficialmente fundada a "Companhia Antarctica Paulista", comprovando que inicialmente a empresa não tinha um foco muito claro de negócios, a companhia atuava na fabricação de cerveja e refrigerantes, produção de banha e presunto, fábrica de gelo e manutenção de câmaras frias para estocagem de alimentos. Em 1893 esteve por decretar a falência, sendo reorganizada e direcionada apenas para a fabricação de cerveja e refrigerantes. Em 2000 a Antarctica funde-se com a Brahma, formando a AmBev, a quinta maior cervejaria do mundo, vendida em 2004 para a empresa belga Interbrew, formando a Anheuser-Buschln Bev.

Sua Vila Operária, destinada aos funcionários mais especializados, possuía 36 casas, com $65 \mathrm{~m}^{2}$ de área construída em cada unidade, sendo sua localização junto à Avenida Presidente Prudente. Sua primeira menção data de 1895. (MIGNOLI, s/d)

18. SMC/ CONPRESP - Antiga Fábrica Antarctica - Resolução 19/2016
A vila operária foi demolida, sendo seu terreno utilizado atualmente como estacionamento para a empresa Ambev. O edifício da fábrica está abandonado, uma vez que as funções da fábrica não são mais exercidas no local. Boa parte deste complexo é tombado pela instância municipal| ${ }^{18}$, que prevê entre outras características a manutenção de parte dos edifícios, elementos externos de sua arquitetura, estruturas metálicas, chaminé e letreiros que identificam o nome da empresa.

\section{Indústrias Reunidas Francisco Matarazzo - Vila Boyes (1911)}

O complexo industrial foi criado por Simeon Boyes na transição dos séculos XIX para o século XX, com o intuito de produzir tecidos, a tecelagem Boyes-Kirk, se localizava no Belenzinho e contava em 1909 com 152 operários. (CENTRO INDUSTRIAL DO BRASIL, 1909)

Pouco tempo depois, o complexo industrial e vila operária foram adquiridos por Francesco Matarazzo em um período em que o empresário buscava a crescente diversificação de sua cadeia produtiva em busca de sua autossuficiência, instalando na unidade fabril uma fábrica dedicada à produção de papelão.

A Vila Boyes concentrava um total de 97 residências assobradadas, que conforme descrições indicam a existência de distintas tipologias, destinadas aos moradores de diferentes hierarquias na fábrica. As casas mais luxuosas e espaçosas eram destinadas aos cargos de maior importância, nestas a ornamentação também possuía 
19. SMC / CONPRESP, Resolução № 06 / 2016.

20. SMC/ CONPRESP (1991) - Resolução 05/1991. CONDEPHAAT (1980) - Resolução 36/1980

usjt • arq.urb • número 24 | janeiro - abril de 2019 maior refinamento. Construída com alvenaria de tijolos, o programa dessas casas introduz a tipologia dos "sobradinhos", com banheiro interno no térreo ao lado da cozinha e dois dormitórios no piso superior. (SANTOS, s/d) As casas geminadas sofreram modificações em sua fachada, eliminando a harmonia do conjunto original. Além das residências, a vila possui três sobrados de dimensões imponentes destinadas à chefia. $O$ conjunto possui tombamento municipal ${ }^{19}$, buscando a manutenção dos remanescentes das características externas do conjunto residencial.

\section{Sociedade Mútua Economisadora / Moinho Santista - Vila Economisadora (1913)}

Em um período onde as legislações urbanas municipais buscavam medidas para a "higienização" urbana da cidade de São Paulo, inúmeras foram as propostas aprovadas para que a iniciativa privada desenvolvesse unidades de habitação voltadas para a classe operária.

Entre os modelos merece destaque a proposta lançada pela Sociedade Mútua Economisadora, que em 1913 lança a Vila Economisadora, nas proximidades da linha férrea e várzea do Rio Tamanduateí. Seu lançamento ocorre inicialmente como vila operária destinada à classe trabalhadora, idealizada a partir do capital privado, não sendo neste primeiro momento, vinculada a nenhuma indústria em especial. Condição alterada apenas em 1935, quando o conjunto foi adquirido por João Ugliengo, presidente do Moinho
Santista, que continua locando os imóveis aos então funcionários de sua indústria instalada na cidade de São Paulo.

O conjunto habitacional, proposto pela Sociedade Mútua Economisadora, destinava-se à classe trabalhadora e à classe média, sendo composto de 134 unidades compostas por residências e armazéns, variáveis conforme 7 tipologias, podendo atingir a metragem de $160 \mathrm{~m} 2$. A ornamentação seguia os preceitos do ecletismo. (CAMPOS, 2008).

O conjunto é tombado pelas instâncias municipal e estadual ${ }^{20}$. Mesmo com ações de incentivo a preservação das características originais das residências, o conjunto apresenta inúmeras alterações, sendo atualmente inserida em um contexto de elevados índices de degradação urbana, reflexo de inúmeras tentativas de implementação de planos urbanísticos e agravamento de crises econômicas.

\section{São Paulo Railway Company - Vila Marquesa de Itu / Vila Inglesa (1916)}

A construção da Vila dos Ingleses se insere no contexto de desenvolvimento da cidade de São Paulo, marcada em grande medida pela industrialização e pela utilização da malha ferroviária. Um contexto em confronto com a constante demanda por moradias em decorrência do elevado crescimento populacional. 


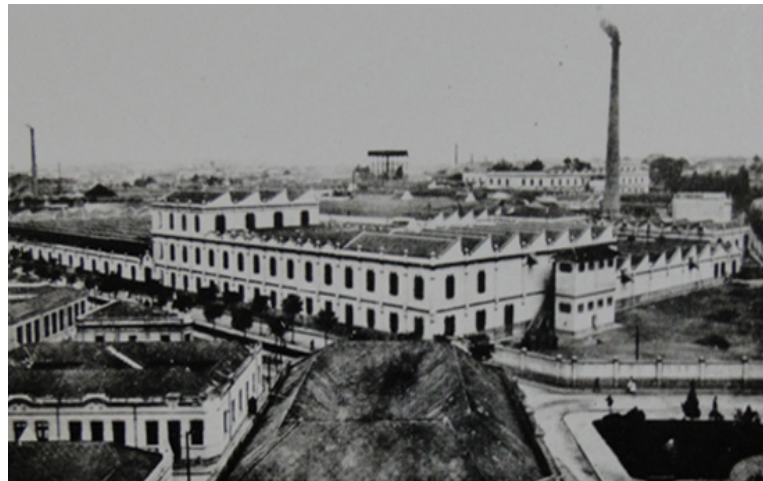

Figura 9. Fábrica e Vila Maria Zélia. Fonte: SCARPA, 1926.

21. Decreto Estadual 48.439 ,

de 21-12-2004

usjt • arq.urb • número 24 | janeiro - abril de 2019
O conjunto de 28 casas assobradadas foi projetado por Germano Bresser, tendo a supervisão do engenheiro chileno Eduardo de Aguiar D’Andrada. Antes de se tornar uma vila para abrigar os engenheiros ingleses, o local era o jardim do palacete de propriedade da Marquesa de Itu.

Após a reestruturação, ocorrida na década de 1980, a Vila dos Ingleses atraiu empreendimentos comerciais ligados à cultura. Em 1988, torna-se um pequeno núcleo de escritórios de arquitetos, designers, fotógrafos e produtores de vídeos. Nos anos 1990 tiveram início os estudos de tombamento. ${ }^{21}$ Atualmente abriga distintas atividades.

\section{Cia. Nacional de Tecidos de Juta - Vila Maria Zélia (1916)}

Em 1908 Jorge Street cria a Companhia Nacional de Tecidos de Juta, que encontra na expansão do cultivo do café um mercado promissor. Em 1924 Street é obrigado a vender a Companhia à família Scarpa e Guinle - Sociedade Anonyma Scarpa (Figura 9). Esta propriedade perdura até 1931. Anos depois, em 1937, parte das instalações da fábrica foi utilizada como presídio. Atualmente, o complexo industrial pertence à Goodyear, restando apenas um trecho do prédio histórico em função do tombamento. Um muro divide as atuais instalações da vila e seu complexo industrial, os edifícios localizados entre estes ambientes foram demolidos (como o jardim de Infância, algumas residências e o campo de futebol). Fábrica e vila perderam sua correlação.
A Vila Maria Zélia, foi projetada pelo arquiteto francês Paul Pedarrieux, a mando de Jorge Street. Estruturada como uma "cidadela", a ornamentação da arquitetura da vila foi realizada sob influência estilística Neogótica, Normanda e Neoclássica.

Considerada a primeira Vila Operária da cidade de São Paulo (1916), reunia dentro de seus domínios todos os equipamentos necessários para a convivência dos operários da fábrica. Originalmente, a vila possuía 220 casas unifamiliares térreas, divididas em sete tipologias variáveis entre 75 e $110 \mathrm{~m}^{2}$.

Os serviços coletivos como: creche; jardim da infância; dois grupos escolares com capacidade de 400 crianças cada um, sendo um para meninos e o outro para meninas; escolas profissionais; igreja; farmácia; dentista; açougue e armazém eram concentrados junto ao acesso principal da vila. Além dos elementos citados, a vila possuía também um campo para jogos esportivos e uma associação para rapazes solteiros. O aluguel, a taxa para o uso da água e as compras do armazém e do armarinho, eram descontados nos salários dos funcionários, apenas a eletricidade era paga individualmente.

A partir de 1931 a Vila começa a perder seu vínculo com a unidade fabril e passa a se caracterizar como "propriedade de aluguel", condição que perdura até 1940 quando o então Instituto de 
Aposentadoria e Pensão dos Industriários (IAPI) adquire a maior parte da Vila e passa a vender as unidades residenciais aos moradores. A partir deste período, com boa parte das casas em mau estado de conservação tem início o processo de descaracterização. Os estudos de Tombamento ${ }^{22}$ iniciam na década de 1980. Atualmente, das 220 casas originais restam 171 , sendo que muitas delas se encontram descaracterizadas apesar do tombamento em nível estadual e municipal. (MAGNANI, 1968)

\section{Cotonifício Crespi - Vila Crespi (1920)}

Fundado pelo italiano Rodolfo Crespi em 1897, no bairro da Mooca, após a importação de teares da Itália. Estrategicamente posicionada próxima à estação da Hospedaria dos Imigrantes, o edifício imponente de três andares e quase $50 \mathrm{mil}$ $\mathrm{m}^{2}$, foi projetado pelo arquiteto italiano Giovanni Battista Bianchi.

Em 1924 os funcionários fundaram o Clube Atlético Juventus, um dos equipamentos incentivados pela companhia. Neste mesmo ano, as instalações da fábrica foram atingidas por um bombardeio da Revolução de 1924. Reconstruída, a empresa passou por períodos de grande prosperidade e só começou a enfrentar dificuldades na década de 1950, em reflexo da obsolescência de seus equipamentos, encerrando suas atividades em 1963.
Segundo antigos operários, a vila foi construída antes de 1920, mas Crespi não ficou muito tempo com as casas. Estas foram vendidas para o Dr. Rondini, antigo médico da fábrica e parente (diziam que era genro) do dono. Os aluguéis eram descontados da folha do pagamento dos empregados. Posteriormente as casas foram vendidas tanto a operários como a outras pessoas interessadas. (BLAY, 1985, p.268)

Assim como todo o bairro da Mooca, os edifícios do cotonifício, vila, estádio e creche enfrentam inúmeras discussões entre a instância pública e privada. Dualizando medidas entre os processos de tombamento e o desenfreado processo de especulação imobiliária e gentrificação descaracterizando boa parte dos remanescentes do complexo. Atualmente as instalações da fábrica são utilizadas por uma unidade de hipermercados do Grupo Pão de Açúcar, os demais equipamentos foram em sua quase totalidade descaracterizados.

\section{Cia de Melhoramentos de São Paulo (1920)}

Em 1920, após algumas alterações em sua estrutura produtiva (passa a se dedicar à produção de celulose), a empresa, inicialmente organizada pelo Coronel Rodovalho, foi incorporada à firma Weiszflog Irmãos, que já atuava no campo das artes gráficas e da produção de artefatos de papel passando a se chamar Companhia Melhoramentos de São Paulo.
(Vila Maria Zélia - Resolução 39/92). CONDEPHAAT 1985 - (Processo- 24268/85. Resolução 43 , de 18/12/1992, $\mathrm{N}^{\circ}$ inscr. 305, p. 77 28/05/1983) 
Possue Cayeiras 650 casas, para operários e administração; 4000 alqueires de terra, quase todos plantados de espécies vegetaes proprias para a industria do papel, como sejam eucalyptos, cruptomea japonica, casuarinas, etc; linha férrea na extensão de 30 kilometros corta a propriedade em diversas direcções; possue 7 escolas com média de frequência de 40 alumnos e um grupo de 100 escoteiros, filiados á Associação Brasileira de Escoteiros; 1500 operarios e suas familias; pharmacia; templo religioso, theatro, hospital em construção, associações recreativas e desportivas, jornal publicado por auxiliares da Companhia, etc, etc (A marca d'água no papel de imprensa e a industria nacional de papel [s.d.]: 38, apud: CORREIA, 1998, p.94-95).

De um modo em geral, as residências eram confortáveis e dotadas de todos os requisitos sanitários exigidos, dispondo de luz elétrica, água encanada, pisos assoalhados e forros de estuque (MORAES, 1995). Além disso, a estrutura da vila oferecia os requisitos básicos para a população operária como escolas, teatro, centros de recreação, armazém. Uma "pequena cidade" (BLAY, 1985), que abrigava os operários, inclusive os especializados em setores da produção de papel, as casas demonstravam alterações conforme a categoria profissional exercida pelo funcionário, que assumia a responsabilidade de bom uso do imóvel cedido pela companhia. Para esta relação era cobrado um "simbólico" valor de aluguel, sendo a manutenção e eventuais reparos de encargo da empresa.
Após a desapropriação de um vasto território de reflorestamento para a construção da Rodovia dos Bandeirantes (1976), o desmonte do núcleo fabril foi intensificado. Na década de 1980 praticamente todas as vilas forma desconstituídas, restando apenas alguns edifícios como "a Igreja Nossa Senhora do Rosário, construída em 1917; as oficinas construídas em 1922; os fornos de barranco construídos em 1877 e os fornos construídos posteriormente, a fábrica, o prédio do Armazém de 1885; o grupo escolar Alfredo Weiszflog e algumas residências permaneceram após o desmonte" (JERONYMO, s/d).

Com o gradativo abandono do complexo e o afastamento da população em reflexo do isolamento (negação de acesso) das instalações da fábrica torna-se crescente o processo de deterioração dos remanescentes. Tentativas de tombamento foram organizadas, entretanto, o projeto municipal encaminhado ao CONDEPHAAT (Lei Orgânica do Município, nº1994/90) foi negado, sendo recomendada apenas a preservação em nível municipal, que ainda demonstra indefinições.

\section{Indústrias Reunidas Francisco Matarazzo - Vila Cerealina (1924)}

O nome "Matarazzo" se tornou sinônimo de empreendimento e desenvolvimento industrial com a criação das IRFM (Indústrias Reunidas Fábricas Matarazzo) em 1911. O complexo industrial (que 
23. A Fábrica Maria Ângela onde boa parte dos moradores da Vila Cerealina trabalhavam é tombada pelo CONPRESP - Resolução $n^{\circ} 38 / 92$. compreendia indústrias variadas) chegou a empregar 6\% da população paulistana em 365 fábricas dos mais diversificados produtos. A ação industrial de Matarazzo previa a busca pela máxima autossuficiência em meio ao seu processo global de produção. Sendo este o motivo de sua atuação em diversos ramos.

De um modo geral, as unidades fabris da Matarazzo na cidade de São Paulo concentravam-se nos bairros Belém, Mooca, Água Branca e Lapa, além das inúmeras unidades construídas em cidades próximas à cidade de São Paulo e seu interior.

Boa parte das vilas operárias edificadas pela Matarazzo tinha como característica o afastamento com as unidades fabris. Em alguns casos, as vilas (conjuntos de residências) eram compradas de empresários dedicados à construção desta tipologia na cidade. Estes não apresentavam programas articulados à sua estrutura. Para suprir a carência, equipamentos eram dispersos pela cidade como o Hospital edificado na Vila Buarque, cuja consolidação também conta com o apoio de outros empresários industriais da cidade.

A Vila Cerealina (início do projeto 1923 e finalização em 1924) foi construída pelas Indústrias Reunidas F. Matarazzo, provavelmente para abrigar seus técnicos mais qualificados, uma vez que as construções possuíam melhores cuidados quan- to ao acabamento, dimensionamento quando comparadas a outras habitações operárias, edificadas na mesma época. ${ }^{23}$

A vila que ocupa uma quadra e possuí um arruamento interno em formato de "y" foi construída a partir de duas tipologias de casas: assobradadas e térreas. As casas assobradadas junto ao alinhamento do quarteirão foram as primeiras a serem edificadas. A maior parte delas possui duas salas, cozinha, dois dormitórios e banheiro. Porém, junto às esquinas há edificações com maior número de cômodos. Em seguida, foram construídas as casas térreas, que se encontram na parte interna do quarteirão. São menores e mais simples do que as assobradas, possuem apenas sala, cozinha, dormitório e banheiro. Originalmente o uso prioritário das edificações era a habitação, porém nas plantas há indicação de que, em duas esquinas, o uso da parte térrea dos sobrados era comercial.

Nos anos 1940, a própria companhia inicia a gradativa venda de unidades residenciais aos funcionários da fábrica. Atualmente boa parte do conjunto de residências possui um enorme índice de alterações das características originais. Entre as moradias ainda existe uma unidade que pertence à família Matarazzo. O conjunto residencial formado pelas casas da antiga vila não é tombado por nenhuma instância. 
Cia. Brasileira de Cimento Portland S.A - Vila Triângulo / Portland / Vila Nova (1926)

Em 1914 é criada a Cia. Industrial e Estrada de Ferro Perus-Pirapora, com o intuito de otimizar o transporte dos romeiros (Pirapora) e da cal extraída na região de Cajamar. Dez anos depois ocorre a criação da Companhia de Cimento Portland S.A por um grupo canadense, sendo posteriormente adquirida pelo grupo Abdalla, que ainda hoje é proprietário da unidade fabril. Sua fundação marca um momento específico da industrialização brasileira, relacionado tanto à sua diversificação produtiva, quanto às memórias operárias.

Ao ressaltarmos a importância da indústria em questão merece destaque o fato de que o cimento produzido pela unidade foi um dos grandes responsáveis pela construção de obras icônicas, entre as quais parte dos edifícios da cidade de São Paulo nos anos 1930, período onde a cidade alavanca sua verticalização, e a cidade de Brasília.

Entre as inúmeras greves que marcaram a trajetória da Companhia merece destaque o conflito que perdura entre os anos de 1962 e 1969. Sete anos de "greve ou guerra" que englobaram além dos funcionários de Perus, sindicatos de outros grupos industriais de propriedade dos Abdalla, em Jundiaí, São Paulo e Pirajuí.

Em 1986 a unidade de Perus é fechada. Em 1987 ocorre o tombamento do trecho Perus-Pirapora, que além do trajeto, previa também a preservação de trilhos, edifícios e maquinários. Em 1992 ocorre o tombamento da fábrica, desde então discussões sobre o futuro deste patrimônio colocam em questão o posicionamento de seu proprietário e comunidade que a mesma se insere e criou.

Considerando a distância e dificuldade de comunicação entre a fábrica e o centro de São Paulo, foram inicialmente construídos em Perus, os edifícios ligados à fábrica, os quartos para solteiros, uma pensão, a Vila Fábrica, a Vila Triângulo e algumas casas para os funcionários ligados à administração. Posteriormente, foi implantada no local a Vila Portland. Da mesma forma, procedeu-se à ampliação junto às jazidas, cujo entorno foi tomado por moradias que formaram a Vila Água Fria e Vila Nova. Escolas, ambulatório, restaurante, entreposto, armazéns, oficinas, igrejas, pensão, clubes e campos de futebol completavam a estrutura. Considerando todas as unidades residenciais, admite-se que cerca de 450 residências foram edificadas.

Em relação à Vila Triângulo (Figura 10), relatos descrevem a existência de aproximadamente 70 residências que foram organizadas a partir do desenho de um triângulo. Em geral as residências não possuíam riqueza na ornamentação de suas fachadas. No local ainda resta a capela, edificada para a utilização dos funcionários. (JERONYMO, 2016) 


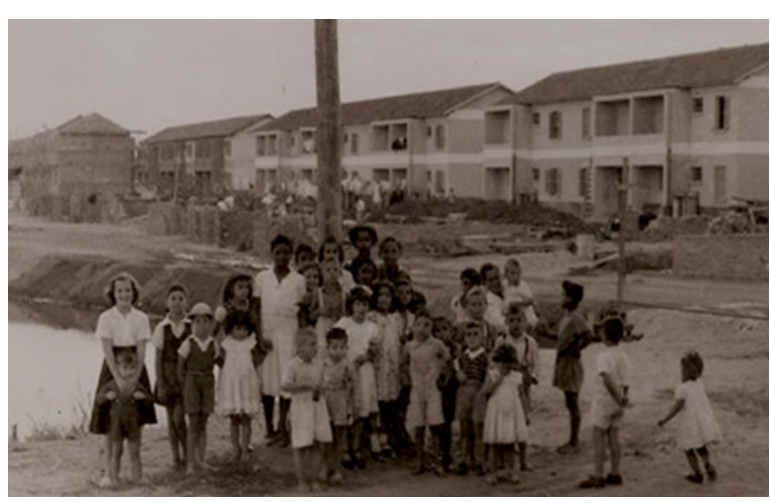

Figura 11: Parte do conjunto residencial Morvan Dias Nadir Figueiredo. Fonte: Marcia Marcos, arquivo pessoal

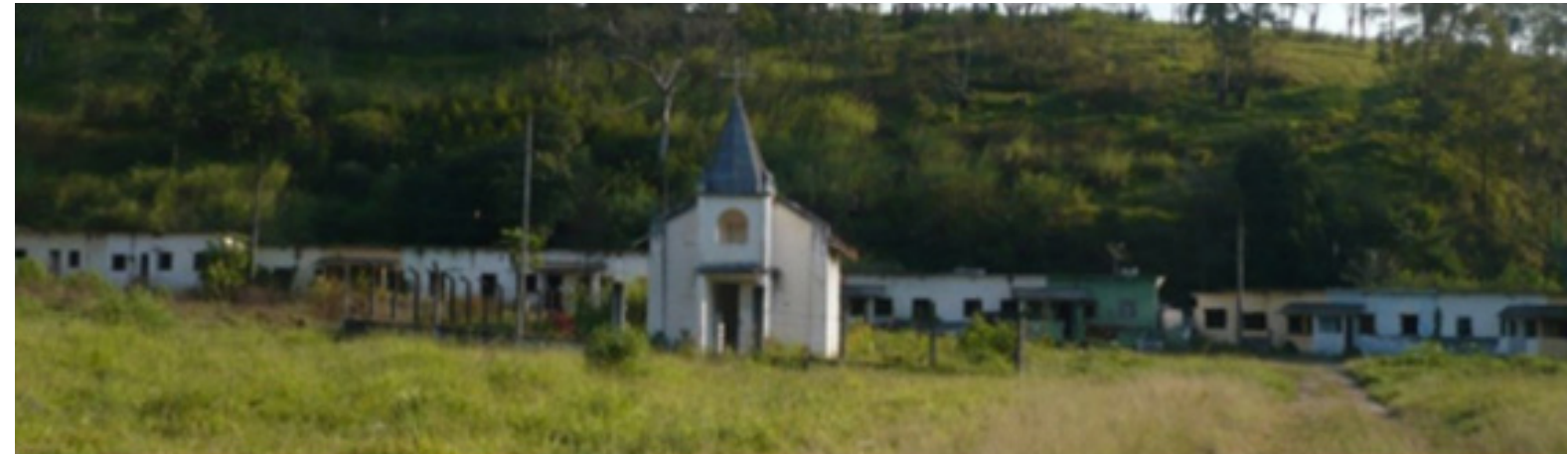

Figura 10: Vila Triângulo. Tomada das residências e igreja. Fonte: JERONYMO,2017.

\section{Nadir Figueiredo - Conjunto Habitacional Mor- van Dias de Figueiredo (1930)}

Fundada em 1912, pelos irmãos Nadir e Morvan Dias de Figueiredo, a Nadir Figueiredo começou como uma oficina de máquinas de escrever. Um ano depois, virou fundição, atuando com a iluminação elétrica na cidade, na década de 30 adotou o vidro como matéria-prima principal. É hoje a maior fabricante de utilidades domésticas de vidro do país.

Conforme os relatos o Conjunto era composto por 300 unidades habitacionais, construídas a partir de blocos residenciais de dois andares, as casas eram assobradadas (Figura 11). Quadras poliesportivas e um campo de futebol garantiam o lazer dos funcionários, que disputavam inúmeras partidas organizadas pela Associação Atlética. Os moradores eram servidos por um posto médico e escola para as crianças, anos mais tar- de uma unidade do SESI foi instalada nas proximidades, oferecendo a alfabetização para as crianças e a capacitação dos funcionários. Próximo à associação existia um pequeno armazém. Em princípio, um lago também marcava a paisagem da vila.

Ao longo do tempo a companhia inicia o desmonte de sua Vila Operária, vendendo parte dos terrenos para empreendimentos como a rede de hipermercados Makro e Carrefour. Outros grupos demonstram interesse na compra de parte da área que antes pertenciam à Vila e Fábrica, reflexo da valorização que as marginais enfrentam com a diversificação econômica da cidade de São Paulo, sentida a partir dos anos 1950. 


\section{Nitro-Química - Vila Americana / Cidade Nitro- química (1949)}

A história da primeira fábrica de rayon (a seda sintética) da América Latina, criada em 1935, se confunde com a dos moradores mais antigos de São Miguel Paulista e com a do desenvolvimento da região. Entre 1937 e 1957, a localidade passa de 7.000 para quase 80 mil trabalhadores. Em função de sua importância ao desenvolvimento da região parte das instalações da fábrica foi tombada pelo CONPRESP.

Além de algumas moradias no interior do amplo terreno ocupado pelas instalações fabris, esta fábrica criou duas vilas operárias: a Cidade Nitro-Química, destinada a empregados em funções estratégicas na fábrica como chefes de departamentos, vigias e operários qualificados, e a Vila Americana destinada inicialmente para engenheiros e técnicos da empresa Tubize Chatillon e depois a gerentes brasileiros. A Vila Americana tem dois trechos: o setor $B$ com traçado mais ou menos ortogonal e ocupado por moradias menores; e o setor $A$, que pode ser identificado com o urbanismo das cidades jardim. Neste setor o traçado é irregular, com vias retilíneas ou curvas modelando quarteirões de formas variadas, enquanto as casas assumem dimensões maiores. Com exceção de um pequeno prédio de apartamentos, todas as moradias são bangalôs térreos ou de dois pavimentos. (CORREIA, 2014)

\section{Fiat Lux - Vila Fiat Lux (1959)}

Situada ao lado do rio Tietê, em Pirituba, a Vila da Fiat Lux (fundada por Swedish Match - 1959) é tida como um modelo de aplicação de parte dos ideais urbanísticos da cidade Jardim, inseridos ao contexto de Vilas Operárias. Seu projeto faz uso do desenho sinuoso para adaptação ao terreno, uma vez que a vila foi implantada em uma encosta, entre o rio e um barranco, cuja base delineia uma via sinuosa. Na área de maior irregularidade foi proposta a utilização intensa de vegetação. No total foram edificadas 72 residências dispostas ao longo de cinco quadras, com formato variado, alimentadas por três ruas, que convergem para uma área verde de uso coletivo. Entre os equipamentos existentes destaca-se a existência de três praças dotadas de coreto e de quadra esportiva. (CORREIA, 2004).

As construções foram edificadas sob a forma de Bangalôs, sendo em sua quase totalidade, geminados e dotados de pequenos jardins. A meia encosta, ao longo da via sinuosa, foram implantados bangalôs mais amplos e jardins mais generosos. Existiam também sobrados de arquitetura moderna, geminados ou agrupadas em pequenos blocos, nos quais os jardins são reduzidos a um pequeno recuo. (CORREIA, 2004) Na década de 1970 estas residências foram alienadas e boa parte dos operários as recebe como indenização ou parte de sua aposentadoria. $O$ conjunto não é tombado por nenhuma instância. A vila não pos- 
sui mais relações com a empresa. Boa parte de suas residências sofreram alterações.

\section{O contexto industrial como testemunho das paisagens culturais: ambientes de articulação e requalificação urbana.}

CONSIDERANDO que os imóveis indicados (edifícios fabris, moradias, serviços, religiosos, passarelas de travessia de estradas de ferro e área ambiental) são testemunhos de técnicas construtivas e de projeto arquitetônico representativos de sua época, ou tem valor afetivo, reconhecido pela população local. (CONPRESP). ${ }^{24}$

Quando se fala ou trata do termo patrimônio, o reconhecimento de seus agentes formadores é fundamental para a compreensão das ações humanas sobre o ambiente construído e sua organização social. Neste sentido, a análise geográfica do ambiente permite a compreensão das formas de apropriação de seu entorno, delineando os rumos que determinada condição histórica tomou ao longo da evolução da sociedade ou comunidade em questão, fatores de extrema importância para a exata compreensão dos fatos históricos e espaciais.

Quando esmiuçada, esta paisagem revela importantes marcas materiais e imateriais de um período fundamental ao desenvolvimento econômico, social e urbano da cidade, Estado e país como um todo. Neste contexto, o simples fato de se tombar um edifício e torná-lo um "monumento" (“intocável”), destiná-lo a prática de atividades culturais e a consequente gentrificação do ambiente em que se insere, ou manter suas atividades "iniciais", não significa necessariamente proporcionar a real preservação de seu significado.

O desafio é fazer com que o patrimônio não seja compreendido apenas como um sinônimo de algo degradado ou ultrapassado, mas sim como algo que represente o contexto em que se encontra, tanto por seu viés histórico, quanto por seu contexto atual, cujos componentes podem ou não passar por alterações de acordo com as novas dinâmicas em que se inserem. Este é o ponto fundamental onde as vertentes materiais e imateriais devem coexistir com o intuito de perpetuar as lembranças, mesmo nos casos em que a degradação ou descaracterização demonstram o domínio do bem tombado.

Ao ser analisado pelo viés da indústria, o patrimônio revela os inúmeros fatores existentes em meio à circulação de conhecimentos, técnicas e ideais, que em seu primeiro momento foram literalmente "copiados", mas que pouco a pouco revelam novos tecnicismos decorrentes das adaptações locais.

Quais os personagens envolvidos neste processo? Engenheiros, empreiteiros, operários, imigrantes e migrantes que construíram o ambiente, não são mais importantes que os moradores e habitantes que convivem e desconhecem o pas-
24. RESOLUÇÃO No 06 / CONPRESP / 2016.

usjt • arq.urb • número 24 | janeiro - abril de 2019 
25. Deve ser destacado aqui o esforço dos moradores, que organizados em uma associação buscam a promoção da história da vila, seja pelo acompanhamento de estudantes, gravações, e atividades culturais na vila.

26. São os casos de personagens como D. Zenilda, Sr. Dilceu e D. Terezinha, personagens entrevistados ao longo do processo de criação do web documentário EntreVilas (http://entrevilasdoc. com.br/), e que narraram com perfeição as complexas relações decorrentes do processo industrial que a cidade de São Paulo enfrenta nos anos 1920 , a partir de suas memórias. sado do local, afinal de contas qual o sentido de um sítio histórico se sua trajetória não pode ser identificada,vivenciada e propagada?

Entre os exemplos citados, o caso da Vila Maria Zélia demonstra o conflito e falta de articulação entre os organismos de preservação e os proprietários das residências da vila. $O$ simples anúncio de que estudos estavam sendo realizados em torno do tombamento do conjunto levantaram o medo da perda do imóvel e uma corrida em busca da "modernização" das residências. A falta de informação e a repressão das intervenções arrastam ainda hoje inúmeros processos. ${ }^{25}$ O vínculo entre a antiga Companhia Nacional de Tecidos de Juta e a Vila Maria Zélia foi rompido, entretanto ainda se escuta todos os dias o apito das fábricas vizinhas sinalizando a rotina e a memória operária que ainda resiste no local, lembrança esta defendida também pela associação dos moradores da Vila que desenvolvem inúmeras ações de valorização patrimonial.

Se de um lado as instituições padecem pela falta de incentivos e políticas públicas capazes de articular as ações de preservação e orientação de diretrizes aos moradores, de outro lado, "pequenas alterações" se multiplicam pela falta do diálogo e acompanhamento.

Tudo deve ser preservado? Não necessariamente. Este pode ser, por exemplo, o caso da Vila Cerealina, onde tanto seus moradores quanto os organismos responsáveis decidem pelo não tombamento do complexo. Entre as razões obviamente deve ser compreendido que a vila não possui características suficientes para atestar a sua excentricidade e importância histórica, entretanto não pode ser vista como um ambiente menos importante.

Fato este comprovado pelo rico encontro de personagens que no auge de seus 90 anos narram de forma brilhante o que a arquitetura não é capaz de revelar. ${ }^{26}$ Neste caso, a memória coletiva torna-se instrumento para a transformação social, que quando bem aplicada estimulam a demanda por novos conjuntos de memórias objetivadas e transmissíveis.

Este também pode ser o caso apresentado pelo contexto de Caieiras, se para o Estado os vestígios industriais não demonstram importância, é válida a discussão se para seus munícipes o complexo industrial revela lembranças, aproximando assim as formas de regeneração deste bem e seu entorno.

A Vila Economizadora, nos remete ao potencial de flexibilização do ambiente histórico, revelando assim as inúmeras camadas que a cidade possui. Inicialmente articulada como vila voltada para a classe média, transforma-se nos anos 1930 em vila operária vinculada às atividades no Moinho Santista. Pouco a pouco a vila se vê inserida em meio aos inúmeros processos de transição eco- 
27. Vale destacar que após as atividades do webdocuentário os proprietários da fábrica voltaram a se aproximar dos líderes da associação Quilombaque, com o intuito de discutirem as propostas de atividades a serem desenvolvidas no ambiente tombado da fábrica.

usjt • arq.urb • número 24 | janeiro - abril de 2019 nômica do bairro em que se insere. Os antigos ruídos das fábricas e trens são pouco a pouco substituídos pelo barulho de automóveis, vendedores e máquinas de costura. A atividade comercial marcante desde os primórdios da vila permite que a mesma resista às transições de seu entorno e não fosse completamente destruída como tantas outras áreas próximas. Seu passado não esconde a degradação, entretanto boa parte das práticas de preservação e restauração permitiu que boa parte das características originais das fachadas das residências fosse preservada. Por dentro das casas são inúmeras as novas camadas, revelando identidades e funções de seus moradores e proprietários.

Outra grande lição nos traz a Vila Triângulo, uma vila operária industrial literalmente suburbana, pertencente a então Cia. Brasileira de Cimento Portland que teve suas atividades encerradas em 1986 e seu anúncio de tombamento decretado em 1992. Compreendida a partir de seu ponto de vista histórico como palco de uma das maiores greves já registradas no Brasil (cuja duração revelam longos 7 anos de conflito) deve ser vista como patrimônio de quem? Inicialmente instalada em uma região suburbana acessível apenas pelo lombo de burros ou por meio dos trilhos da então São Paulo Railway, ainda revela em seu território (responsável pelo delineamento de boa parte do atual contexto de Perus) a pobreza em equipamentos sociais, um contraste quando analisada a partir de sua rica história escondida em meio ao viés da luta e resistência social ${ }^{27}$.
O questionamento sobre qual o real público deste monumento, se consolida entre o conflito de seus proprietários e a comunidade local que pleiteia a utilização das ruínas da fábrica como um complexo cultural local. Em seu discurso a proposta da empresa revela as futuras intenções culturais do complexo: um projeto que mascara a forte especulação imobiliária sofrida ao longo de toda sua região, principalmente após a concretização do trecho Norte do Rodoanel Mario Covas, transformando mais uma vez a região em uma área estratégica para a economia, vestida agora pelo viés imobiliário, afastando definitivamente a população por meio de um "tombamento de fachada" que barra a população do acesso ao ambiente histórico.

O patrimônio industrial deve ser considerado como uma parte integrante do patrimônio cultural. Contudo, a sua proteção legal deve ter em consideração a sua natureza específica. Ela deve ser capaz de proteger as fábricas e as suas máquinas, os seus elementos subterrâneos e as suas estruturas no solo, os complexos e os conjuntos de edifícios, assim como as paisagens industriais. As áreas de resíduos industriais, assim como as ruínas, que devem ser protegidas, tanto pelo seu potencial arqueológico como pelo seu valor ecológico. (TICCIH - CARTA DE NIZHNY TAGIL, 2003).

Neste contexto, conforme as delimitações propostas pela Chancela da Paisagem Cultural Brasileira (IPHAN. Portaria $\left.n^{\circ} 127\right)$, “(...) o patrimônio cultural é formado por bens de natureza material e imaterial, tomados individualmente ou em con- 
junto, portadores de referência à identidade, à ação, à memória dos diferentes grupos formadores da sociedade brasileira, nos quais se incluem as formas de expressão, os modos de criar, fazer e viver, as criações científicas, artísticas e tecnológicas, as obras, objetos, documentos, edificações e demais espaços destinados às manifestações artístico-culturais, os conjuntos urbanos e sítios de valor histórico, paisagístico, artístico, arqueológico, paleontológico, ecológico e científico", o que permite classificarmos o contexto delineado por fábricas e vilas como detentores deste potencial, justificando assim, medidas que permitam a identificação e valorização de seus contextos como paisagens culturais.

Em um período em que as relações sociais e cotidianas são cada vez mais construídas no mundo virtual, proporcionar ao usuário diferentes experiências de imersão em contextos históricos (ricamente caracterizados por seus vestígios patrimoniais materiais e imateriais), poderia ser uma saída para a promoção de sua valorização e reconhecimento. Os resultados podem ser conferidos por moradores, pesquisadores, viajantes e internautas curiosos, que a partir de celulares, tablets ou computadores podem experimentar a navegação pelas vilas operárias de São Paulo pela plataforma virtual do webdocumentário disponível no endereço <www.entrevilasdoc.com. br>. Informações e eventos podem também ser conferidos em <https://www.facebook.com/entrevilasdoc/>.

\section{Bibliografia:}

A Obra Social da Companhia Melhoramentos - casas operárias em Caieiras (impressões do Sr. Luis Carlos Mancini transcritas em Serviço Social n. 24, São Paulo dezembro de 1940). Caieiras, Companhia Melhoramentos de São Paulo, 1940.

BAUER, Marcelo. Os webdocumentários e as novas possibilidades de narrativa documental. In: Cross Content, Brazil. Disponível para consulta: <http://webdocumentario.com.br/Os_ webdocument $\% \mathrm{C} 3 \% \mathrm{~A} 1$ rios_e_as_novas_possibilidades_da_narrativa_documental_Marcelo_ Bauer.pdf> acesso em: mai. de 2018.

BENCLOWICZ, Carla M. Prelúdio Modernista: construindo a habitação operária em São Paulo. Dissertação (mestrado) - FAU-USP, São Paulo, 1989.

BONDUKI, Nabil G. Origens da Habitação Operária no Brasil. São Paulo, Estação Liberdade: FAPESP, 1998.

BLAY, Eva Alterman. Eu não tenho onde morar: vilas operárias na cidade de São Paulo. São Paulo: Nobel, 1985.

BRANDÃO, Ignácio Loyola. Santa Marina - um futuro transparente. São Paulo: DBA - Dórea Books and Art, 1996. 
BRUNO, Ernani Silva. História do Brasil, Geral e Regional. Grande Oeste (Goiás e Mato Grosso). Volume 6. São Paulo: Editora Cultrix.

CAMPOS, Eudes. Vila Economizadora. Informativo Arquivo Histórico Municipal, 4 (19): jul/ago.2008. Disponível para consulta: <http:// www.arquivohistorico.sp.gov.br> acesso em: mai 2018.

CASTELLS, M. A era da informação: economia, sociedade e cultura. Lisboa, Fundação Calouste Gulbenkian, 2002.

Centro Industrial do Brasil. Brasil suas riquezas naturais, suas indústrias, 1909.

Conférence: Comment assurer la pérennité des nouvelles formes de documentaires? Disponível para consulta: <http://leblogdocumentaire.fr/ regardez-direct-conference-mit-open-documentary-lab-perennite-nouvelles-formes-de-documentaires/> Acesso em: mai. 2018.

CORDEIRO, Simone Lucena (Org.). Os cortiços de Santa Ifigênia: sanitarismo e urbanização (1893). São Paulo: Imprensa Oficial do Estado de São Paulo / Arquivo Público do Estado de São Paulo, 2010.

CORREIA, Telma de Barros. A construção do habitat moderno no Brasil. 1870-1950. São Paulo, RiMa, 2004.
CORREIA, Telma de Barros. A cidade-jardim: os conjuntos residenciais de fábricas (Brasil, 19181953). Anais do Museu Paulista. São Paulo. n. sér. v.22. n.1. p. 161-198. jan.- jun. 2014.

CROU, Olivier. Qu'est-ce qu'un webdocumentaire? 2010. Disponível para consulta: <http:// webdoc.fr/>. Acesso em: jul. 2018.

DEAN, Warren. A industrialização de São Paulo. Corpo e alma do Brasil. São Paulo: Difusão Europeia do Livro, Editora da Universidade de São Paulo.

DONATO, Hernâni. 100 Anos de Melhoramentos. São Paulo: Melhoramentos, 1990.

ENGELS, Frederich. A situação da classe trabalhadora em Inglaterra. Lisboa, Editorial Presença: Livraria Martins Fontes, 1975.

INSTITUTO DO PATRIMÔNIO HISTÓRICO E ARTÍSTICO NACIONAL. Portaria $\mathbf{n}^{\circ} \mathbf{1 2 7}$, de 30 de Abril de 2009. Estabelece a chancela da Paisagem Cultural Brasileira. Diário Oficial da União, n83, 5 de maio de 2009.

JERONYMO, Vanice. O Público e o Privado na construção do espaço urbano: o caso de Caieiras. Disponivel para consulta: <http://www.iau. usp.br/sspa/arquivos/pdfs/papers/01540.pdf>. Acesso em: mai. 2018. 
JERONYMO, Vanice. Conflitos, impasses e limites na preservação do patrimônio industrial paulista: o caso da Perus (CBCPP). Tese de Doutorado. São Carlos: Instituto de Arquitetura e Urbanismo, USP, 2016.

LANGENBUCH, Juergen Richard, edc. L275. A estruturação da grande São Paulo - estudo de geografia urbana. Rio de Janeiro, Instituto Brasileiro de Geografia. Departamento de Documentação e Divulgação Geográfica e Cartográfica.1971.

LEMOS, Carlos A. C. Alvenaria Burguesa: breve história da arquitetura residencial de tijolos em São Paulo a partir do ciclo econômico liderado pelo café. São Paulo, Nobel, 1985.

LIMENA, Maria Margarida Cavalcanti. Avenida Paulista: Imagens da Metrópole. São Paulo: EDUC, 1996.

MACHADO, Ruth. Museus virtuais: Aimportância da usabilidade na mediação entre o público e o objeto museológico. In: Livro de Actas do $4^{\circ}$ SOPCOM, pp. 1540-1547. Disponível para consulta: <http://bocc.ubi.pt/pag/muchacho-rute-museus-virtuais-importancia-usabilidade-mediacao.pdf> Acesso em: jul. 2018.

MARX, Karl. Trabalho assalariado e capital. Editorial Vitória Ltda. 1954
MAGNANI, Luis Antonio Cambiaghi. Curso de especialização em restauração e conservação de monumentos e conjuntos históricos. DPH, 1968.

MATOS, Odilon Nogueira de. Café e Ferrovias. A Evolução Ferroviária de São Paulo e o Desenvolvimento da Cultura Cafeeira. São Paulo: Alfa-Omega. 1974.

MEYER, Regina Maria Prosperi; et. al. São Paulo Metrópole. São Paulo, EDUSP, Imprensa Oficial, 2004.

MILLIET, Sérgio. Roteiro do Café e outros ensaios. $3^{a}$ edição. Coleção do departamento de Cultura, vol. XXV, São Paulo, 1938.

MIGNOLI, Denis Jesus. Análise qualitativa da vila operária da Companhia Antarctica Paulista. In: $15^{\circ}$ Congresso Nacional de Iniciação Científica. CONIC/SEMESP. Disponível para consulta: $<$ http://conic-semesp.org.br/anais/files/2015/trabalho-1000020085.pdf>. Acesso em: abr. 2018.

MORAES, Marcilio Dias. Caieiras fatos e Personalidades da "Cidade dos Pinheirais". São Paulo: Parma, 1995.

MOUTINHO, M. A construção do objecto museológico. Lisboa, Cadernos de Sócio museologia, n¹, ULHT, 1994. 
Observatoire du documentaire. 2011. Disponível para consulta: <http://obsdoc.ca/> Acesso em: jul. 2018.

PINTO, Adolfo, A Istória da viação pública de São Paulo. São Paulo: Tip. de Vanordem, 1903.

PRADO JR., Caio. História Econômica do Brasil. $31^{a}$ ed. São Paulo: Editora Brasiliense, 1976.

RODRIGUES, Angela R. Estudo do patrimônio industrial com uso fabril na cidade de São Paulo. São Paulo: Dissertação (Mestrado) - Faculdade de Arquitetura e Urbanismo, Universidade de São Paulo, São Paulo, 2011.

SALGADO, Ivone Salgado; SOUSA, Diógenes. A Companhia Antarctica Paulista em São Paulo: memória e patrimônio edficado. In: Revista arq. urb, n. 19, maio - agosto de 2017. Disponível para consulta: <http://www.usjt.br/arq.urb/numero-19/4-ivone-salgado.pdf $>$. Acesso em: abr. 2018.

SANTOS, Regina Helena Vieira. Vilas Operárias como patrimônio Industrial. Como preservá-las? DPH- Departamento do Patrimônio Histórico. PMSP
SÃO PAULO (Estado). Decreto no. 233, de 2 de março de 1894. Estabelece o Código Sanitário. Assembléia Legislativa do Estado de São Paulo, São Paulo, SP. Disponível para consulta: <https:// www.al.sp.gov.br/norma/137356>. Acesso em: mai. 2018.

SCARPA, Nicolau. Lembranças da Vila Scarpa. [São Paulo: s.e.], 1926.

TRAMONTANO, Marcelo C. Paris - São Paulo Tokyo: novos modos de vida, novos espaços de morar. Tese (doutorado) - FAU-USP, São Paulo, 1998

VITORINO, Bruno Besso. Patrimônio ameaçado: os grupos residenciais construídos até 1930 no Brás, Mooca e Belém. Dissertação de Mestrado apresentada a Faculdade de Arquitetura. São Paulo. Universidade de São Paulo. 2008. 